\title{
The history of bears (Ursidae, Carnivora, Mammalia) from Silesia (southern Poland) and the neighbouring areas
}

\author{
Adrian MARCISZAK ${ }^{1, *}$ and Grzegorz LIPECKI ${ }^{2}$ \\ 1 University of Wrocław, Department of Palaeozoology, Institute of Environmental Biology, Faculty of Biological Sciences, \\ Sienkiewicza 21, 50-335 Wrocław, Poland \\ 2 Polish Academy of Sciences, Institute of Systematics and Evolution of Animals, Sławkowska 17, 31-016 Kraków, Poland
}

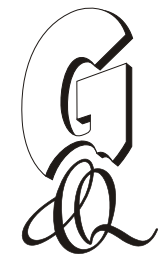

\begin{abstract}
Marciszak, A., Lipecki, G., 2020. The history of bears (Ursidae, Carnivora, Mammalia) from Silesia (southern Poland) and the neighbouring areas. Geological Quarterly, 64 (4): 876-897, doi: 10.7306/gq.1565
\end{abstract}

Associate Editor: Michał Zatoń

Revision of the Silesian bear fauna, based on material from 152 sites, mainly cave and karstic localities, and also archaeological and open-air sites, shows the presence of 13 forms and species. These records encompass the last $16.5 \mathrm{Ma}$ and may be divided into five main morphophyletic groups. The oldest bears, represented by the genera Ballusia and Ursavus, are dated to 16.5-11 Ma, and belonged to the stem forms of the subfamily Ursinae. After a break of $6 \mathrm{My}$, the earliest members of the genus Ursus appeared, and all known Pliocene bears in Silesia belong to the genus Ursus were identified as Ursus minimus. They represent one or two migration events. Additionally, between 3.6 and $3.2 \mathrm{Ma}$, a single occurrence of Agriotherium insigne was recorded from the Węże 1 site. A few Early Pleistocene bear records are represented by U. etruscus, which was a probable ancestor of both arctoid and spelaeoid bear lineages. The oldest representative of Ursus ex gr. arctos known so far and assigned to $U$. a. suessenbornensis is known from one latest Early Pleistocene (1.2-0.9 Ma) locality, while other Polish records of this form require confirmation. The first occurrence of $U$. deningeri, the oldest taxon within the U. ex gr. deningeri-spelaeus lineage, was recorded from $\sim 700 \mathrm{ka}$ deposits in Silesia. During the pronounced cold period of MIS 12, the Scandinavian ice sheet covered almost the entire modern territory of Poland, with the exception of the Sudetes and the Carpathians. The accompanying drastic faunal turnover led to the formation of the pan-Eurasian Mammoth Fauna at $\sim 460 \mathrm{ka}$. At that time a characteristic member of this fauna, the steppe brown bear Ursus arctos priscus, a specific ecomorph adapted to live in open grasslands, appeared in this region. It survived until the beginning of MIS 1, when modern Ursus arctos arctos appeared in Silesia and survived to the present day. U. deningeri was the most common bear during the Middle Pleistocene, while the first records of $U$. spelaeus spelaeus appeared since MIS 7 . The latter form was replaced by $U$. ingressus during the Late Pleistocene $(\sim 110-100 \mathrm{ka})$. Spelaeoid bears totally dominated the cave assemblage, and finally vanished between 27 and $24 \mathrm{ka}$.

Key words: taxonomy, Miocene, Pliocene, Pleistocene, ursid lineages.

\section{INTRODUCTION}

Finds of different representatives of the family Ursidae are frequently made in Poland, and their highest density has been recorded from the cave and karstic sites of Silesia and immediately neighbouring areas. Palaeontologically this region is one of the most prolific in Poland. Bear records from Silesia and nearby areas allow us to reconstruct the regional history of the family over the last $\sim 16 \mathrm{My}$. This timespan is, though, incompletely covered, and there are some gaps, especially in the middle Miocene to Middle Pleistocene interval.

\footnotetext{
* Corresponding author, e-mail: adrian.marciszak@uwr.edu.pl Received: April 14, 2020; accepted: September 17, 2020; first published online: November 12, 2020
}

Bears spread all over the Northern Hemisphere during the Miocene and gave rise to a considerable number of species, from which a single one has survived to the present in Poland. The Silesian history of bears started with the earliest Polish record of Ursavus elmensis from the Przeworno 2 site dated to 16-14.5 Ma. This taxon is also generally considered to be the earliest undisputed bear species (Baryshnikov and Lavrov, 2015). The Miocene genus Ursavus Schlosser, 1899 is regarded as a direct ancestor of modern ursine bears of the genus Ursus Linnaeus, 1758. Bears in Silesia have been almost exclusively represented by species of Ursus over the last $4 \mathrm{My}$, with the exception of a single occurrence of Agriotherium that persisted from the Miocene (Stach, 1953, 1957; Wolsan, 1989).

Ursine bears have existed in Silesia continuously since the Middle Pliocene, from $\sim 4 \mathrm{Ma}$. Although only sporadic in some intervals, bears became one of the dominant mammal groups during the Middle and Late Pleistocene. This paper provides a general overview of the history and taxonomy of ursine bears in Silesia and the nearest neighbouring areas, as a critical review 
of the literature complemented by our own research results. Size and morphological analyses are supplemented by uranium-thorium (UTh) and accelerator mass spectrometry (AMS) dating methods as well as by DNA analysis.

\section{MATERIAL AND METHODS}

The subdivision of the family Ursidae Fischer, 1814 into five subfamilies: Ursinae Fischer, 1814, Arctotheriinae F. Ameghino, 1903, Ailuropodinae Grevé, 1892, Agriotheriinae Kretzoi, 1929, and Ursavinae Kretzoi, 1945 is made sensu Wagner (2010). According to this conception, all Eurasian representatives of the Ursinae subfamily discussed in this paper may be assigned to the genus Ursus. The taxonomic overview was made according to main groups of Eurasian bears sensu Mazza and Rustioni (1994): (1) minimus-thibetanus, (2) etruscus, (3) arctos, and (4) deningeri-spelaeus. The definition and subdivisions of the Quaternary Period follow Gibbard and Cohen (2008) and Gibbard and Head (2009a, b). The definition and subdivisions of mammal zones and their correlation with the chronostratigraphic scale as well as the MN-zones follow Gliozzi et al. (1997) and Fejfar et al. (1998). The nomenclatural codification follows the 4th edition of the International Code of Zoological Nomenclature (ICZN, 1999). Capital and lowercase letters, $\mathrm{P} / \mathrm{p}$ (premolars), and $\mathrm{M} / \mathrm{m}$ (molars), refer to upper and lower cheek-teeth, respectively.

The area included in the analysis coincides with the historical boundaries of Silesia (Provinz Schlesien) as shown by Pax (1921, 1925), with some minor modifications (Fig. 1). At present, Silesia covers $\sim 50,000 \mathrm{~km}^{2}$; it extends along the Odra River and is mostly located in Poland, with small parts in the Czech Republic and Germany (Fig. 1; Czapliński et al., 2007).

Radiocarbon dates were made in the Poznan Radiocarbon Laboratory following their pre-treatment protocol for the extraction of collagen (Longin, 1971; Piotrowska and Goslar, 2002). Before extraction, the degree of collagen degradation is checked by measuring the content of nitrogen and carbon in bone, using a Flash EA 1112 Series (Thermo-Scientific) analyser. The samples are regarded suitable for collagen dating if nitrogen content in bone is $\geq 0.6 \%$, and the $\mathrm{C} / \mathrm{N}$ ration is $\leq 5$. Suitable bones are crushed mechanically to granulation $<0.3 \mathrm{~mm}$, the bone powder is then treated with $2 \mathrm{M} \mathrm{HCl}$ (room temp., $20 \mathrm{~min}$ ), and $0.1 \mathrm{M} \mathrm{NaOH}$ (room temp., $1 \mathrm{~h}$ ). After each step of treatment, the sample is centrifuged and the residuum is collected. Extraction of collagen is processed in $\mathrm{HCl}$ $\left(\mathrm{pH}=3.80^{\circ} \mathrm{C}, 10 \mathrm{~h}\right)$, and after centrifuging the residuum is removed. The extracted collagen is then ultrafiltered on pre-cleaned Vivaspin 15 MWCO 30 kD filters. The quality of the collagen is ultimately assessed based on the $\mathrm{C} / \mathrm{N}$ atomic ratio (interval of acceptance: $2.7-3.5$ ) and collagen extraction yield (acceptance threshold: $0.5 \%$ ). On demand, carbon and nitrogen stable isotopic composition of the collagen can be determined (Bronk Ramsey et al., 2004).

\section{TAXONOMIC PART}

Revision of the Silesian and neighbourhood bear fauna based on 152 sites, mainly cave and karstic, but also archaeological and open-air, showed the presence of 13 bear taxa (Fig. 1 and Appendix $1^{*}$ ). The records covered the last $16 \mathrm{Ma}$, and were divided into five main groups. The importance of this family in the palaeofaunas grew significantly, and from the Middle Miocene bears became important members of the palaeoguilds. By that time there had already been established a model of bear evolution, based on a large, solid animal, mostly omnivorous or carnivorous, able to compete with even the largest active carnivores like big cats. In the last $15 \mathrm{My}$ on almost all continents (expect Australia) a large bear, Agriotherium earlier, Arctodus or Ursus later, which played an important role as a scavenger of and competitor to other large carnivores.

During this evolution, the size of members of the Ursinae subfamily also grew considerably (Fig. 2). The earliest Silesian bear, $B$. elmenensis, was the size of a lynx, while their direct descendants of the genus Ursavus were already the size of a large wolf. Pliocene forms like U. minimus were comparable in size with the modern Himalayan black bear Ursus thibetanus Cuvier, 1823. Despite its relatively large dimensions, $A$. insigne from the Węże 1 site is a medium-sized member of the genus Agriotherium. The Early Pleistocene $U$. etruscus reached the size of a modern Central European brown bear. Ursids reached their maximum size in the Middle and especially Late Pleistocene, where deningeroid and spelaeoid bears dominated in caves and were the largest Eurasian bears. Comparable in size with them, and even exceeding them as regards large males, was the largest carnivore in Silesia and indeed in Eurasia in general, the Ice Age steppe brown bear U. a. priscus (Fig. 2).

\section{MIOCENE (16-5 Ma)}

The oldest undisputed Silesian bear species is Ballusia elmensis (Stehlin, 1917) from the Przeworno 2 site dated to 16-14.5 Ma. This form occupied a stem position among ursine taxa (Qiu et al., 2014). The genus apparently dispersed from Asia into North America and Europe at $\sim 20 \mathrm{Ma}$, as shown by a large number of fossils in Europe grading toward eastern Asia (Qiu et al., 2014). This small bear (comparable in size to the Eurasian lynx Lynx lynx (Linnaeus, 1758) is characterized by proportionally small M2 with short and narrow talon. According to Baryshnikov and Lavrov (2015), B. elmensis was probably a small arboreal animal with an omnivorous diet. This species is rarely noted in Central Europe, for instance at the German sites Wintershof-West (type locality for MN3; Dehm, 1950) and Hambach 6C (Mörs et al., 2000)

True members of the genus Ursavus, $U$. brevirhinus (Hofmann, 1887) and U. primaevus (Gaillard, 1899), are the next two ursine bears recorded from Silesia. Both species can be regarded as the descendants of $B$. elmensis (sensu Ginsburg and Morales, 1998), and were recorded mostly from central Silesia. $U$. brevirhinus had a long timespan from 18-11 Ma (MN 4-9). This species was widely distributed across Europe: Steieregg and Voitsberg (MN 5), and Göriach (MN 6), all in Austria (Hoffmann, 1887; Koken, 1888; Hoffmann, 1892; Schlosser, 1899a, 1899b; Thenius, 1949a, 1949b); Opole 1 (14-13 Ma) and Gliwice-Sośnicowice in Poland (14-11 Ma) (Wegner, 1908, 1913; Koenigswald, 1925; Helbing, 1936), and Can Llobasteres (11.1-9.7 Ma) in Spain (Crusafont-Pairo and Kurtén, 1976). U. brevirhinus from Can Llobasteres represents the largest and the most advanced specimen, while individuals from Gliwice-Sośnicowice strongly varied in size. According to Qiu et al. (2014), they apparently comprise two forms, small and large, and according to them only the small maxilla with M1-M2 in Wegner (1913: pl. XII-16) can be assigned to $U$. brevirhinus. This interpretation cannot be entirely ruled out, 


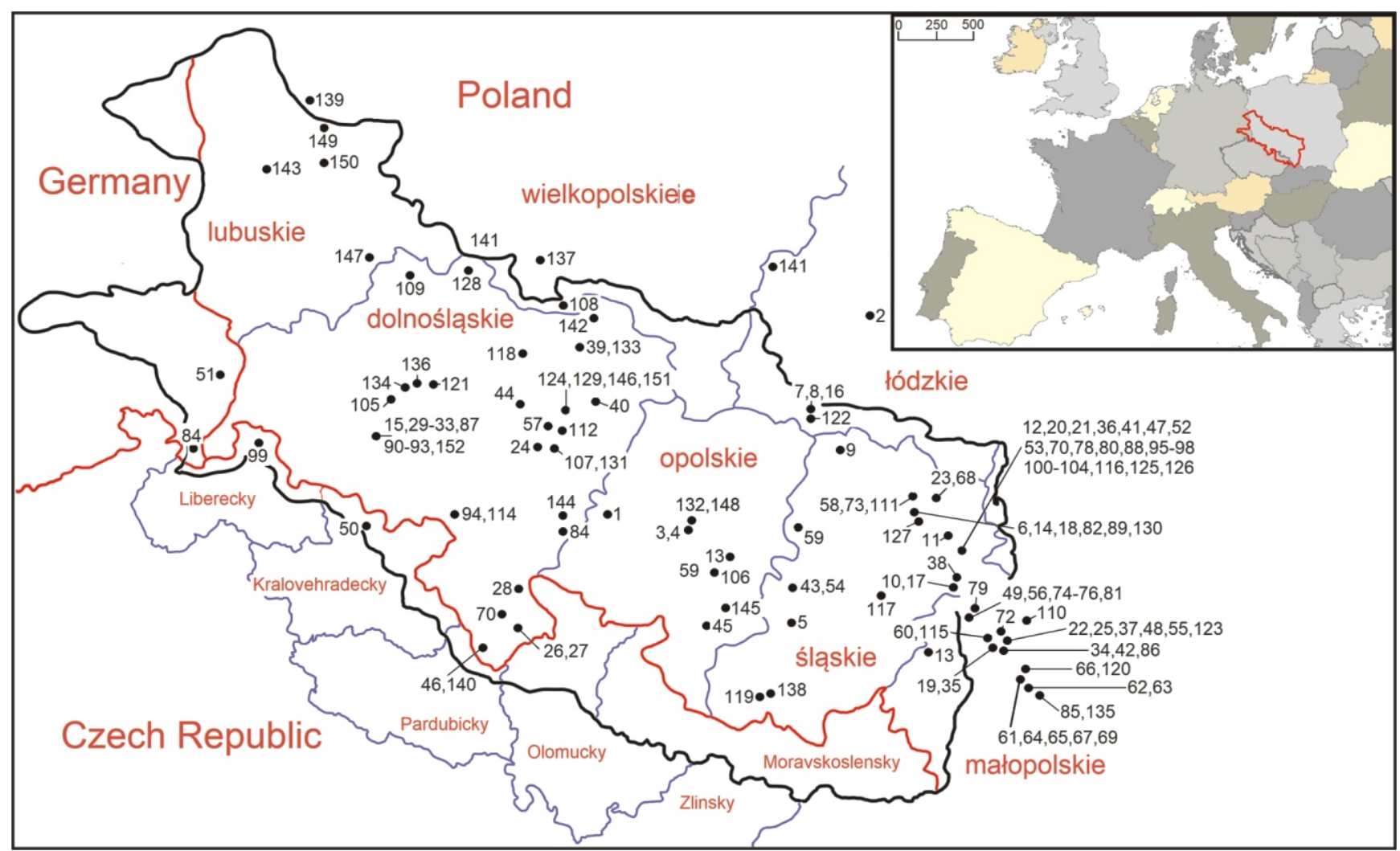

Fig. 1. Localities in Silesia and neighbouring areas with bear remains, discussed in the text, in chronological order

The Silesia boundary is superimposed on modern national borders, indicated by black lines. State boundaries are indicated by red lines, and administrative boundaries are indicated by blue lines. In the insert showing the location of Silesia in Europe, the Silesia boundary (in red) is superimposed on modern national borders; Miocene: 1 - Przeworno 2; 2 - Bełchatów B; 3 - Opole 1; 4 - Opole 2; 5 - Gliwice-Sośnicowice; Pliocene: 6 - Pańska Góra; 7 - Węże 1; 8 - Węże 2; 9 - Rębielice Królewskie-Kamieniołom, by the cemetary; Early and Middle Pleistocene: 10 - Jasna Strzegowska cave; 11 - Żabia cave; 12 - Zamkowa Dolna cave, fauna C; 13 - Tunel Wielki cave; 14 - Przymiłowice C; 15 Południowa cave; 16 - Draby 2, 3, 5, 8 and 9; 17 - Biśnik cave, layers 19ad-14; 18 - Deszczowa cave, layers 1-4; 19 - Nietoperzowa cave, layers 18-14; 20 - Stajnia cave, layers H-G; 21 - Komarowa cave, lowermost layers; 22 - Ciemna cave, layers 19-17; Late Pleistocene: 17 - Biśnik cave, layers 12-1; 18 - Deszczowa cave, layers 5-8; 19 - Nietoperzowa cave, layers 13-3; 20 - Stajnia cave, layers F-B; 21 Komarowa cave; 22 - Ciemna cave, layers 16-2; 23 - Dziadowa skała cave, layers 3-4; 24 - Imbramowice; 25 - Koziarnia cave; 26 Niedźwiedzia cave; 27 - Miniaturka cave; 29 - Wschodnia cave; 30 - Naciekowa cave; 31 - Północna Duża cave; 32 - by Wschodniej cave; 33 - caves of Mt Połom; 34 - Wierzchowska Górna cave; $\mathbf{3 5}$ - Wylotne shelter; 36 - Niedźwiedzia Górna cave; 37 - Łokietka cave; 38 Perspektywiczna cave; 39 - Winna Góra; 40 - Skarszyn; 41 - Towarna cave; 42 - Mamutowa cave; 43 - Pyskowice; 44 - Rakoszyce; 45 Pawłowiczki; 46 - Solna Jama cave; 47 - cave 4 on Mt Birów; 48 - Bębłowska Dolna cave; 49 - caves near Olkusz; 50 - cave near Horní Lánov; 51 - Schöpstal-Kunnersdorf; 52 - cave 5 in Złoty Potok; 53 - Grota Niedźwiedzia cave; 54 - Dzierżno; 55 - Główna w Kopcowej Górze cave; $\mathbf{5 6}$ - Gorenicka cave; $\mathbf{5 7}$ - Kąty Wrocławskie; $\mathbf{5 8}$ - Koralowa cave; $\mathbf{5 9}$ - Lubliniec; $\mathbf{6 0}$ - Łabajowa cave; 61 - Murek cave; 62 - na Gołąbcu cave; 63 - nad Galoską cave; 64 - na Gaiku 2 shelter; 65 - na Miłaszówce cave; 66 - na Wrzosach Północna cave; 67 - nad Matką Boską cave; 68 - Okiennik cave; 69 - pod Kochanką cave; 70 - Pośrednie shelter; 71 - Rogóżka cave; 72 - Sadlana cave; 73 - shelter no 1 in Srocko; 74 - Większe w Krzyżowej Skale; 75 - w Ogrójcu Górne shelter; 76 - w Okopach Wielka Dolna cave; 77 - shelter no. 6 in Złoty Potok; 78 - shelter no. 7 in Złoty Potok; 79 - Sypialnia cave; $\mathbf{8 0}$ - Wiercica cave; 81 - Zbójecka cave; 82 - Zegar cave; 83 - Ziębice; 84 Zittau (Żytawa);85 - Kraków Spadzista; 86 - Maszycka cave; Holocene: 15 - Południowa cave; 17 - Biśnik cave, layer 1ab; 18 - Deszczowa cave, layers 9-11; 19 - Nietoperzowa cave, layers 2-1; 20 - Stajnia cave, layers B-A; 21 - Komarowa cave, uppermost layers; 22 - Ciemna cave, layers 2-1; 23 - Dziadowa skała cave, layers 9-13; 26 - Niedźwiedzia cave; 29 - Wschodnia cave; 30 - Naciekowa cave; 32 - by Wschodniej cave; 87 - Aven in Połomie cave; 88 - Babie Nogi shelter; 89 - Berkowa cave; 90 - Cisowe 1 shelter; 91 - Cisowe 2 shelter; 92 Panna shelter; 93 - Trwoga Paleontologa shelter; 94 - Głuszyca-Górna; 95 - Górne shelter above Stajnia cave; 96 - Krucza Skała shelter; 97 - Maurycego cave; 98 - Kryształowa cave; 99 - Medvědia cave; 100 - Ruska Skała shelter; 101 - Olsztyńska and Wszystkich Świętych caves; 102 - Studnisko cave; 103 - Trzebniowska cave; 104 - Wierna cave; 105 - Wilczy Dól shelter; 106 - Świętej Anny Mt.; 107 - Ślęża Mt; 108 - Szkaradowo; 109 - Głogów-Nosocice; 110 - Miechów; 111 - Wilcze shelter no 3; 112 - Domasław; 113 - Kamień Śląski; 114 Rogowiec casttle; 115 - Borsuka cave, layer 3; 116 - cave no. 3 on Mt Birów; 117 - Grodziec; 118 - Łazy; 119 - Kietrz; 120 - on Wrzosach Południowa cave; 121 - Grzybiany 1; 122 - Działoszyn; 123 - Ojców castle; 124 - Karczna Góra; 125 - shelter no. 3 in Smoleń; 126 - in Kostkowice shelter; 127 - Zielona cave; 128 - Góra 1; 129 - Wrocław Marii Magdaleny street; 130 -in Zielonej Górze cave; 131 - Strachów; 132 - Opole; 133 - Trzebnica; 134 - Rzymówka; 135 - Kraków-Square Market; 136 - Legnica; 137 - Debnica; 138 - Racibórz; 139 Santok; 140 - Szczerba castle; 141 - Sieradz; 142 - Kaszowo 1; 143 - Krosno Odrzańskie; 144 - Niemcza; 145 - Kędzierzyn-Kożle; 146 Wrocław-Ostrów Tumski; 147 - Bytom Odrzański; 148 - Opole-Ostrówek; 149 - Międzyrzecz 1; 150 - Grodziszcze; 151 - Wrocław-Nowy Targ; 152 - Małgorzaty shelter 


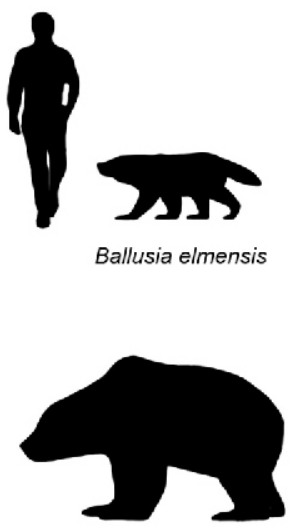

Ursus deningeri

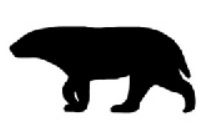

Ursavus brevirhinus

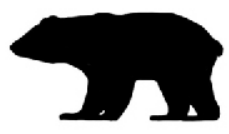

Ursus minimus

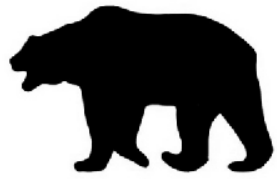

Agriotherium insigne

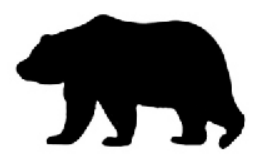

Ursus etruscus

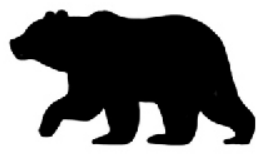

Ursus arctos arctos

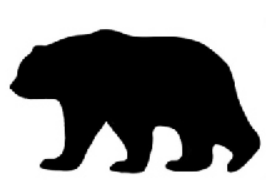

Ursus spelaeus rossicus

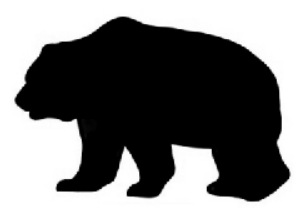

Ursus spelaeus spelaeus

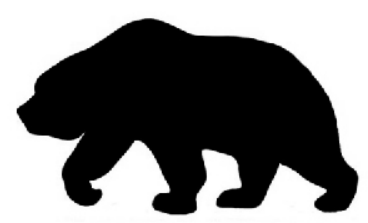

Ursus ingressus

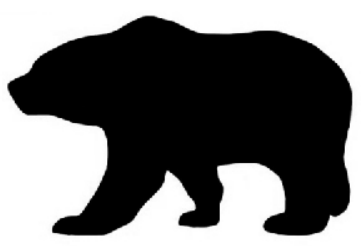

Ursus arctos priscus

Fig. 2. Size comparison of different Silesian bears

Ballusia elmensis - Przeworno 2 (16-14.5 Ma), Ursavus brevirhinus - Opole 1 (14-13 Ma), Ursus minimus and Agriotherium insigne - Węże 1 (3.6-3.2 Ma), U. etruscus - Żabia cave (1.7-1.5 Ma), U. arctos arctos - Wschodnia cave (14.3-13.2 ka), U. deningeri - Draby 3 (440-400 ka), U. rossicus - Naciekowa cave (60-40 ka), U. spelaeus spelaeus - Biśnik cave, layers 15-13 (200-130 ka), U. ingressus and U. arctos priscus - Niedźwiedzia cave (100-35 ka); all bears are adult males shown at the same scale, compared with a man $1.8 \mathrm{~m}$ high

though an alternative explanation of sexual dimorphism or intraspecific variability is also possible. This species has also been noted in some far undescribed material from Bełchatów $B$ (14.5-13.8 Ma, Kowalski and Rzebik-Kowalska, 2002), situated $\sim 50 \mathrm{~km}$ north of the historical boundary of Silesia

The second species, $U$. primaevus appeared later in the fossil record, at between 15 and $11 \mathrm{Ma}$ (MN6-9); it has been noted from 4 localities within Silesia. Firstly, it was described from Opole 2, situated $1 \mathrm{~km}$ from Opole 1, discovered by researchers of the Department of Palaeozoology, University of Wrocław. Opole-2 is believed to be somewhat younger (12-11 Ma) than Opole 1, and some authors suggested possible co-occurrence of $U$. primaevus and $U$. brevirhinus (Wolsan, 1989; Kowalski, 1990). This is of course possible, but more a better explanation is that the two species come from two stratigraphically different levels. These species differ in a number of size-related and morphological features, and overall comparison of both forms shows the younger evolutionary level of $U$. primaevus. When compared with $U$. brevirhinus, $U$. primaevus is larger ( $\mathrm{m} 1$ length is $15-18 \mathrm{~mm}$ for $U$. brevirhinus and $17-20 \mathrm{~mm}$ for $U$. primaevus), $\mathrm{P} 3 / \mathrm{p} 3$ and $\mathrm{p} 4$ are broader and have equal crown heights, P4 lacks a parastyle, the talon of M2 is proportionally broader and longer, and $\mathrm{m} 1$ has a shorter and more oblique paraconid, a less open valley between the paraconid and metaconid, a relatively higher protoconid with more steeply mesial and distal slopes, and a shorter talonid (de Bonis et al., 2018). Besides Opole 2, $U$. primaevus in Silesia has also been recorded from Gliwice-Sośnicowice, by Qiu et al. (2014) based on large specimens described previously by Wegner (1913) as belonging to $U$. brevirhinus. Besides Silesia (Poland), this species has also been noted from La Grive-Saint-Alban in France (Gaillard, 1899; Depéret and Llueca, 1928), and Can Ponsich in Spain (Crusafont-Pairo and Kurtén, 1976).

\section{PLIOCENE (5-2.58 Ma)}

Subsequently in the history of Silesian bears there is a wide (6-7 My) gap without any fossil material until the Late Pliocene locality Węże 1, dated to 3.6-3.2 Ma. This remarkable locality has yielded 115 vertebrate species (including 9 amphibians, 15 reptiles, 4 birds, 30 insectivores, 11 bats, 1 lagomorph, 27 ro- dents, 14 carnivores, 2 perissodactyls and 2 artiodactyls) (Samsonowicz, 1934; Stach, 1953, 1957, 1959; Nadachowski et al., 1989; Kowalski, 1989a, b; Wolsan, 1989; Kowalski, 1990; Rzebik-Kowalska, 2009; Stefaniak, 2015), and remains of two different bears have been found. Among these, broken upper teeth and better preserved lower i 3 and $\mathrm{m} 1$ of a big bear-like animal have been recorded. Based on a few fragments (right maxilla with $M 1-M 2$, left $M 2$, right $P 4$ and $M 1$, left mandible, left $\mathrm{i} 3$ and left and right $\mathrm{m} 1$ ), that probably belonged to one individual, Stach (1957) established a new, rather poorly defined species Agriotherium intermedium. Members of the genus Agriotherium were widely distributed across Europe, India, China, North America and South Africa, and existed between 13.5 and $2.5 \mathrm{Ma}$ (Hendey, 1972, 1974; Jiangzuo and Flynn, 2019). After the first description by Wagner (1837) as Hyaenarctos, and later amended to Agriotherium by Sellards (1916), with increasing finds of new material, mostly fragmentary, Agriotherium gradually became a large heterogeneous genus. After Stach's (1957) paper, nothing was done with the Węże 1 material, and later authors (e.g., Wolsan, 1989; Kowalski, 1990) continued to use the name A. intermedium without paying attention to the insufficient description. Only recently, after a detailed revision of old, and addition of some new, material, it became clear that this name is no longer valid as a separate species and should be synonymised with Agriotherium insigne (Gervais, 1859); this was already pointed out by Jiangzuo and Flynn (2019). Agriotherium from Węże 1 is slightly smaller than $A$. insigne from other localities, but preserved dentition shows the same morphological features, such as a well-developed cingulum. The small observed differences between Agriotherium from Węże 1 and $A$. insigne may be explained due to geographic or chronological differences, since this site is younger than other European records of this species (Jiangzuo and Flynn, 2019). In some features, Agriotherium from Węże 1 resembles also Agriotherium roblesi Morales and Aguirre, 1976, known from the Spanish site Venta del Moro (6.8-4.9 Ma, Morales and Aguirre, 1976). However, in other morphological features, and above all in size, $A$. roblesi, which is a huge bear, so differs from Agriotherium from Węże 1 that cannot be assigned to this species.

From its great size and some dental and cranial features like a short broad rostrum, pre-masseteric fossa on the mandible and robust sectorial carnassials, some previous authors 
(e.g., Kurtén, 1967; Hendey, 1972, 1980) described Agriotherium as highly carnivorous animal predating large terrestrial mammals. However, other authors, in view other features such as long, gracile limbs, have suggested this animal was highly carnivorous, but obtained most of its diet by scavenging (Sorkin, 2006; Oldfield et al., 2012). A large Agriotherium looks like a savage carnivore able to catch almost any animal in its habitat. But this first impression is deceptive, as Agriotherium has a proportionally short but broad snout, typical for the carnivores with strong jaws. Analysis has shown that Agriotherium had one of the strongest bite forces known among the members of the order Carnivora (Sorkin, 2006). By being able to crack open bones, this animal could access one of the most nutritious parts of an animal - the bone marrow - which can last for several years after an animal's death when encased inside the bones. However, postcranial bones of Agriotherium characterise it as a large but relatively underpowered animal that does not seem to have the skeletal framework necessary to cope with high stresses, such as those expected to be encountered while undergoing extreme physical exertion during catching and subduing large struggling prey. Putting that all together, it may be concluded that Agriotherium was the first Silesian specialised scavenger. Being larger than any other carnivore within the fauna from Węże $1, A$. insigne could in effect have scared smaller carnivores away from carcasses of their prey, and obtained this food by kleptoparasitism. This bear may have also supplemented its diet with plants and, as one of the first specialised scavenger bears, was eventually replaced by more advanced forms of another bear genus, as well as possibly by other bone crunching animals such as hyenas. $A$. insigne has been recorded from two older, dated to 4.9-4.2 Ma (MN14) localities, i.e. Montpellier in France (Gervais, 1853, 1859a, b; Stehlin, 1907; Viret, 1939) and Alcoy-Mina in Spain (Montoya et al., 2006). In this context, the Polish record from Węże 1 may be regarded as one of the very late European occurrences of this species (and of members of the genus Agriotherium as well), followed only by those from the Vialette locality in France (3.2-3.1 Ma, Helbing, 1932; Lacombat et al., 2008).

The process of formation of the modern Silesian mammal fauna started at $\sim 4.5-4 \mathrm{Ma}$. It was the time of appearance of the first modern mammalian genera as well as start of the development of mammalian assemblages similar or identical to modern ones. Among them, carnivores were very diverse, and bears became an integral part of these faunas from the beginning. However, the exact time and place of the origin of this lineage remain unknown. The Węże 1 locality has yielded, in addition to A. insigne, also second, a much smaller bear species. Ursus minimus, described originally as Ursus wenzenis (Stach, 1953) is better studied and described on the basis of more abundant material (at least 250 skeletal elements such as skulls, mandibles, isolated teeth and other bone fragments; Ryziewicz, 1969). This earliest representative of the genus Ursus in Europe first appeared in the Early Pliocene (4.9-4.7 Ma, MN14) in the Montpellier locality in France, from which the molars still bear some Ursavus-like characters (Wagner, 2006, 2010). This bear is known from a few sites located mostly in SE Europe, dated to 4.5-4.2 Ma: Kuchurganian beds (Ukraine, Korotkevich, 1967), Baraolt-Căpeni, known also as Barót-Köpecz (Romania, Schlosser, 1899a, b, c; Maier von Mayerfels, 1929), and Dorkovo (Bulgaria, Delson et al., 2005), but also from Iberian sites such as Alcoy-Mina (Spain, Montoya et al., 2006), We have also assigned a few isolated teeth (mostly of limited taxonomical value) from Pańska Góra, dated at 4.9-4.2 Ma, to this form. The exact evolutionary relationships of these bears to Ursavus as well as to later forms remain unclear. In this paper, we agree with the assignment of these bears to $U$. minimus as proposed by Morlo and Kundrát (2001) and Baryshnikov (2007); the latter author has named this form as Ursus minimus boeckhi (Schlosser, 1899). This contrasts with the opinion of Wagner et al. (2011) who supposed that these bears compose a separate migration event and probably also represent a separate species.

While U. minimus has been recorded only from Perpignan at 4.2-3.6 Ma (MN15a) (France, Wagner, 2010), this species became more numerous and spread across Europe from England to the Caucasus between 3.6 and 3.2 Ma (MN15b). Localities with the most representative material are Kvabebi (3.2-2.5 Ma; Vekua, 1972), Odesa Catacombs (3.5-3 Ma, Rosin, 1956), Osztramos 7 (2.8-2.5 Ma; Jánossy, 1978), Gaville (3.2-2.5 Ma; Berzi, 1966), Layna (3.6-3.2 Ma; Soria and Morales, 1976), Les Etouaires (2.8-2.5 Ma; Mazza and Rustioni, 1994) and Węże 1 (Ryziewicz, 1969). According to Wagner (2010), these bears represent a new (at least a second) migration wave of black bears into Europe. They were a little bigger and more advanced in tooth morphology than their earlier relatives. Between MN 15b to MN 16b, they evolved with small changes, and the fossil material of $U$. minimus from Węże 2 (2.4-2.2 Ma) differs from the older bears of Węże 1 mostly in being slightly larger, while morphologically these specimens are very similar.

\section{EARLY PLEISTOCENE ( 2.0-0.9 Ma)}

After 2.0-1.8 Ma U. minimus Devčze \& Bouillet, 1827 was replaced in Europe by Ursus etruscus (Rustioni and Mazza, 1993b; Wagner, 2010; Wagner et al., 2011). The latest occurrence of $U$. minimus in Europe is known from the Poggio Rosso locality in Italy (Mazza et al., 2005), as well as from Villány 3 (Kormos, 1937; Wagner, 2010; Wagner et al., 2011) and probably also Kisláng in Hungary (Kretzoi, 1954; Wagner, 2010; Wagner et al., 2011). An Asiatic newcomer, U. etruscus appeared in Europe from 2-1.8 Ma and became a constant presence at European Early Pleistocene localities. Because the Polish material of this species is revisited in detail in the second paper in this volume, here we only note that this species has been recorded from three Polish sites, all located in Silesia.

The interval between 1.2 and 1.0 Ma in Europe was a time when the earliest representatives of two well-known bear lineages, namely arctoid and spelaeoid, appeared and became dominant in European faunas over the next $1 \mathrm{Ma}$. It was also a time when both lineages started to evolve independently, leading to omnivory and opportunism in arctoid bears and herbivory and specialisation in spelaeoid bears. The earliest specimens are still very similar, and it is not always easy to distinguish arctoid and spelaeoid bears. Rustioni and Mazza (1993b) suggested that members of Ursus ex gr. arctos occur already around 1.3-1.0 Ma. Latter the same material was re-examined and assigned to other forms. The bear from Vallonet was identified as $U$. deningeri von Reichenau, 1904 in Baryshnikov (2007), and from Pirro Nord as U. etruscus Cuvier, 1823 (Petrucci and Sardela, 2009). All these concepts were important breaks in the concepts of European bear taxonomy and phylogeny (Wagner, 2010).

Excellent material from Deutsch-Altenburg (most of the bones came from DA4B, dated to 1.2-1.1 Ma; others are from DA2C1 and DA49, dated to 1.4-1.2 Ma) was regarded as an early representative of the brown bear Ursus arctos suessenbornensis Soergel, 1926 (Rabeder et al., 2010). These authors also assigned to this form some bears from sites dated to 1.1-0.9 Ma such as Untermaßfeld, Ceyssaguet and various sites in Atapuerca. Previously, these specimens had been de- 
scribed under various names - $U$. rodei Musil, 2001 and U. dolinensis García et Arsuaga, 2001 (García and Arsuaga, 2001; Musil, 2001). We agree with like Olive (2006), Rabeder and Withalm (2006) and Rabeder et al. (2010) that these names are junior synonyms of $U$. arctos. In contrast to this, some authors (Baryshnikov, 2007; Argant, 2009) considered that these bears are the oldest known representatives of $U$. deningeri (Wagner, 2010). From 0.9-0.8 Ma there are also known some early arctoid-like bears, though showing some spelaeoid or even thibetanus-like features. For example, there is material from the Sackdilling cave in Germany and Žírany in Slovakia (Heller, 1956; Ambros et al., 2005; Baryshnikov, 2007; Wagner and Sabol, 2007; Wagner, 2010).

The earliest representatives of spelaeoid bears appeared in Europe approximately at the same time as did the bears from the arctoid lineage, and the period between 1.4 and $1.2 \mathrm{Ma}$ is regarded as a splitting time of both lineages (Wagner, 2006 2010). From the time between 1.1 and $0.9 \mathrm{Ma}$, the records of early $U$. deningeri are rare, and known only from a few European sites such as Vallonet cave (Moullé, 1992; Baryshnikov, 2007; Argant, 2009; Wagner, 2010) and Les Valerots in France (Erbaeva et al., 2001), Cal Guardiola in Spain (MadurellMalapeira et al., 2009), and Honce (Wagner and Sabol, 2007) and Mosbach 1 in Germany (von Koenigswald and Tobien, 1987). However, some authors assigned the material from the Vallonet cave to the arctoid lineage (García, 2003), and its conspecificity with $U$. arctos sensu Rabeder et al. (2010) cannot be totally rejected (Wagner, 2010).

Records of $U$. deningeri during the latest Early Pleistocene $(1.0-0.8 \mathrm{Ma})$ are also very sporadic. Among these, there are German sites Dorn-Dürkheim 3 (Franzen, 1999), Hohensülzen (Storch et al., 1973), Würzburg-Schalksberg (Mäuser, 1987), and Russian localities Port-Katon (Bajguševa et al., 2001) and Akhalkalaki (Baryshnikov, 2007). Since the Middle Pleistocene, this bear became common and abundant in most of Europe and bears from the deningeroid and later spelaeoid lineage became dominant until the end of the Pleistocene. Remains of $U$. deningeri were obtained from the following early Middle Pleistocene localities: Gombasek (Slovakia; Kretzoi, 1938 Wagner and Gasparik, 2014); cave C718, Koněprusy caves, Chlum 1 and 4 (Czech Republic; Fejfar, 1976; Fejfar and Heinrich, 1983; Wagner 2004, 2005, 2010); Voigstedt (Germany Horáček and Ložek, 1988), Jagsthausen (Germany; Koby, 1952), Kövesvárad (Hungary; Jánossy, 1963), Kozi Grzbiet (Poland; Wiszniowska, 1989), Slivia (Italy; Ambrosetti et al., 1979), and Tiraspol (Moldova; David, 1982).

\section{MIDDLE PLEISTOCENE-HOLOCENE (700 ka - PRESENT) Ursus ex gr. arctos}

Some problematic specimens that may also belong to arctoid bears have been found in materials from the early and mid-Middle Pleistocene sites, 0.8-0.6 Ma (Wagner, 2010). Among them, there are bear remains from Süßenborn (Soergel, 1926), West Runton (Rabeder et al., 2010), Kövesvárad (Jánossy, 1963), Cueva Mayor, Hundsheim (Rabeder et al., 2010) and Chlum 4 (Wagner, 2004, 2010). The oldest arctoid bear in Silesia is from the Południowa cave dated to $0.6-0.5 \mathrm{Ma}$, but it is not the oldest Polish record of an arctoid bear. The material from Kozi Grzbiet is older; a few isolated teeth found here may represent in fact $U$. arctos. Based on the description and comparison of material from Deutsch-Altenburg with other European material, Rabeder et al. (2010) suggested arctoid bears between 1.4 and $0.6 \mathrm{Ma}$ compose a rather uni- form group, $U$. a. suessenbornensis. This was diagnosed as a medium-sized brown bear which differs from extant $U$. arctos only by having slightly shorter and wider extremities (Rabeder et al., 2010). Proportionally shorter and more robust metapodial bones are a characteristic feature of almost all late Middle and Late Pleistocene brown bears. Narrowing of metapodial bones occurred as late as in the latest part of the Late Pleistocene and in the Holocene (Rabeder et al., 2010; Wagner, 2010). Remains of this bear species have been noted so far in fauna $\mathrm{C}$ of the Zamkowa Dolna cave in Silesia. New excavations at this site may provide new material belonging to this interesting form.

The long period of cold and continental climatic conditions between 480 and 420 ka (MIS 12, Elsterian or San 2 glacial in Poland) drastically changed the Silesian and Palaearctic faunal pattern (Kahlke et al., 2011; Kahlke, 2014). It covered almost all of Poland and also almost the entire Silesian territory. Species of Central Asian steppe origin spread into northern and western Palaearctic regions. This was part of a longer period lasted between 0.8 and $0.4 \mathrm{Ma}$, and characterized by the beginning of a new episode in Earth history, called the Mid-Pleistocene Transition or Middle Pleistocene Revolution (MPR) (Maslin and Ridgwell, 2005; Clarck et al., 2006). Low-amplitude, 41 ky climate cycles were replaced progressively by high-amplitude, 100 ky cycles. The latter cycles implied a transition towards a non-linear forced climate system, and were accompanied by a substantial increase in global ice volume at $0.94 \mathrm{Ma}$ (Maslin and Ridgwell, 2005). These climate changes, particularly the increasing severity and duration of cold stages, had a profound effect on biota and the physical landscape, especially in the Northern Hemisphere (Kahlke et al., 2011; Kahlke, 2014).

One of the very first faunal assemblages termed the Mammoth Fauna, associated with steppe-tundra conditions, was the fauna recorded from meltwater gravels deposited at $\sim 460 \mathrm{ka}$ in Bad Frankenhausen; this locality comprises more species adapted to cold and continental environments, such as Bison sp., Soergelia elisabethae, Praeovibos priscus, Rangifer tarandus ssp., Equus sp. and Mammuthus trogontherii (Kahlke and Lacombat, 2008; Kahlke, 2014). Elements of steppe and tundra origin co-occurred, and the structure of the Mammoth Fauna appeared for the first time.

The period between 420 and 300 ka was the time of the formation of a large carnivore guild which partially survived until the Holocene and dominated over the last $300 \mathrm{ky}$. The stem of this paleoguild comprised Canis lupus ssp., Vulpes vulpes, Ursus spelaeus group, Ursus arctos ssp., Gulo gulo, Panthera spelaea ssp., and Crocuta crocuta spelaea. Their remains though are outnumbered in fossil sites by the bones of spelaeoid bears, constituting up to $98 \%$ at some localities; this bear was not a carnivore, but a herbivore, and in rare cases an omnivore (Marciszak et al., 2011, Krajcarz et al., 2016).

The main competitor to large active carnivores such as the steppe wolf Canis lupus spelaeus, the cave lion Panthera spelaea spelaea and the cave hyena Crocuta crocuta spelaea, was Ursus arctos priscus. Similarly to the steppe wolf, the steppe brown bear is not a different species but a form, something like an "ecotype", a special ecomorph adapted to open habitats (Marciszak et al., 2016, 2017, 2019a, b, 2020). The great size of this bear, commonly documented in Late Pleistocene brown bears from many European sites, may have been an adaptation to colder and more barren habitats (Erdbrink, 1953, 1967; Ehrenberg, 1955; Kurtén, 1956, 1959, 1968; Thenius, 1956; Musil, 1964; Ballesio, 1983; Sabol, 2001a, b; Baryshnikov and Boeskorov, 2004; Pacher, 2007; Rabeder and Frischauf, 2016; Marciszak et al., 2017, 2019a, b).

Among thousands of cave bear bones, from time to time, remains of the arctoid bear, which is distinct in size and mor- 

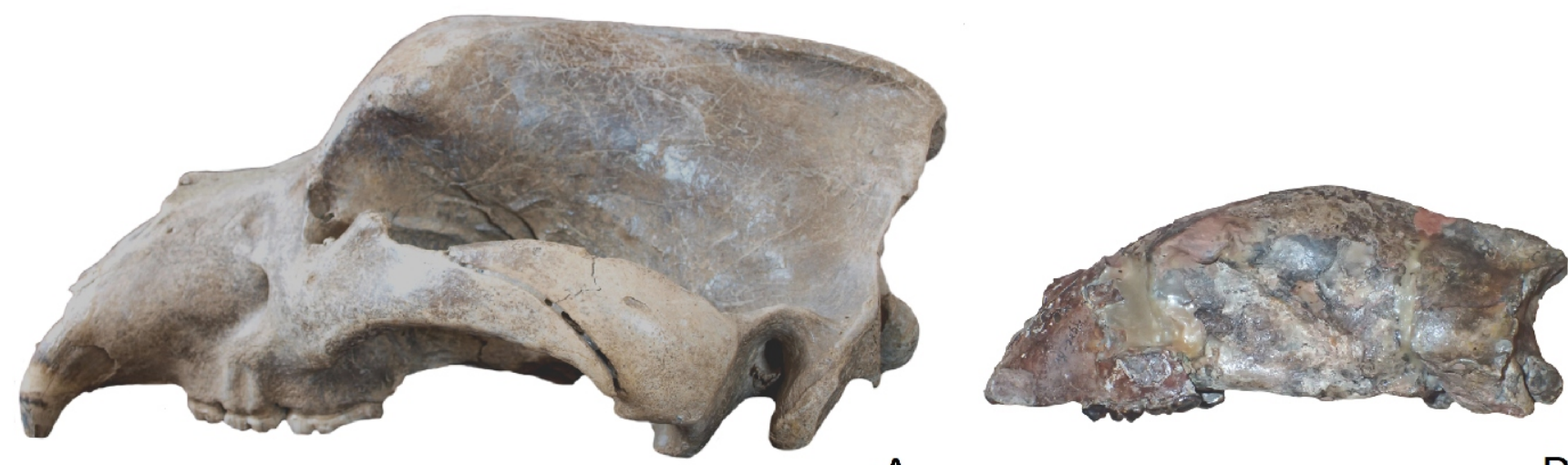

A
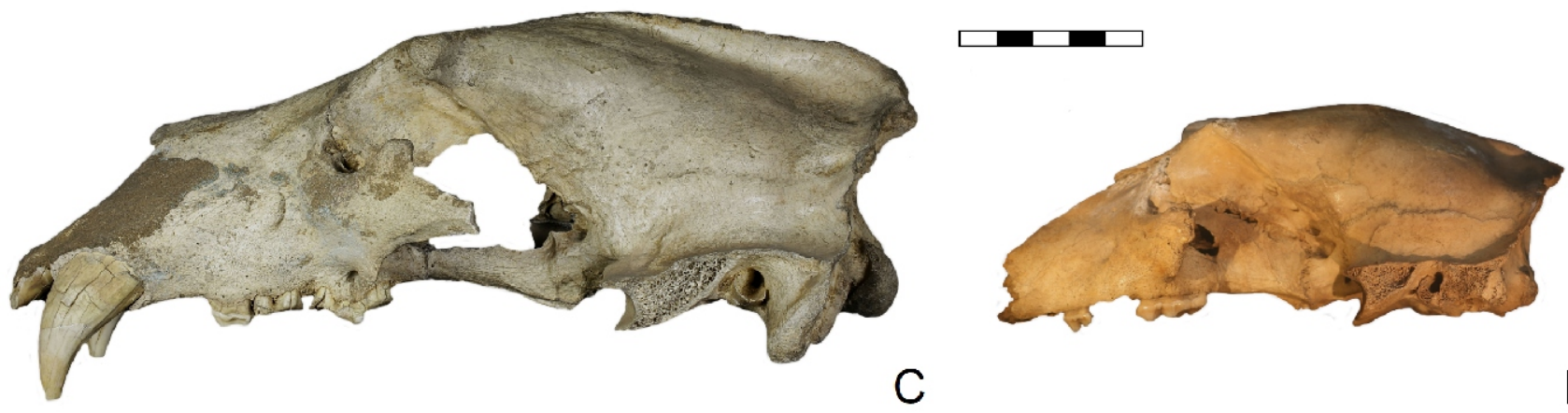

Fig. 3. Skulls of different bears from Silesia and neighbouring areas

A - Ursus ingressus (>) from Niedźwiedzia cave, Poland (50-40 ka, coll. no. ZP UWr/JNK/Us/1); B - Ursus minimus (>) from Węże 1, Poland (3.6-3.2 Ma, coll. no. MF/833/1); C - Ursus arctos priscus (>) from Bohdalec, Czech Republic (22.8-22.2 ka, coll. no. R 1916/824); D - Ursus $\operatorname{arctos} \operatorname{arctos}(>)$ from nad Zagonem cave (Zielona cave, Tatra Mts), Poland (3-1 ka, coll. no. ISEZ MF/7390); all skulls shown in lateral view, scale bar $100 \mathrm{~mm}$

phology from the average modern brown bear, and has been classified under different names: U. ferox, U. horribilis, $U$. anglicus, $U$. priscus, $U$. arctoideus etc. (see the synonymy in Erdbrink, 1953 for details). Dimensions of some individuals, comparable in size with big cave bears, and the similarity in cranial and postcranial and especially in the dental material, caused some authors to suggest possible hybridisation between these forms (Ehrenberg, 1938). It was described as very large bear, with a flat forehead, broad teeth and proportionally robust and short metapodials (Fig. 3; Musil, 1964; Rabeder and Withalm, 2006; Baryshnikov, 2007; Rabeder et al., 2010; Marciszak et al., 2019a). Among the teeth, morphologically particularly outstanding from "typical arctoid morphology" are M2 and $\mathrm{m} 3$, broadened and enlarged in comparison with equivalent teeth of $U$. a. arctos (Figs. 3 and 4). Rode $(1931,1935)$ had already noted that the teeth of $U$. a. priscus are in size and morphology half way between those of arctoid and spelaeoid bears. Klaatsch (1906: 282) noted: "As a particular animal from the end of the ice age, the cave bear (Ursus spelaeus) has almost equal importance with mammoth and reindeer. At the same time, the brown bear (Ursus arctos) and the grey bear (Ursus ferox) also lived in Europe, and their remains appeared already in the Palaeolithic layers; the last of these transcended the ferocity and size of a cave bear, and was the most dangerous enemy of diluvial man". Similarly, Beushausen (1906: 535) mentioned the presence of an "immense grey bear", which lived at the same time as the brown and cave bear.

$U$. arctos is generally more carnivorous in open landscapes (Bojarska and Selva, 2012). Brown bear as a species is a classic example of Bergman's rule, where an increase in body size towards the north in the Northern Hemisphere is observed
(Figs. 3 and 4). However, this pattern is not constant in nature and there are populations living in relatively southern locations, whose average body size, due to e.g. constant or periodic availability of high-protein food, was significantly larger than those of individuals in other populations living at similar latitudes (Mattson and Merrill, 2002; Baryshnikov, 2007). Duringits long temporal range, the body size of this species was subject to strong fluctuations which were influenced by various factors, especially the climate and the type of available food.

The presence of Ursus arctos priscus in cave sites showed that this animal regularly visited caves, most probably in search of food. It is less probable that this large bear denned or hibernated in the time when they were occupied by spelaeoid bears, and most of remains found in caves belonged to very large and robust animals, most probably males. Radiocarbon dates obtained for Ursus arctos priscus showed that this form occurred in Silesia throughout the entire MIS 3 and MIS 2. It was present during even the coolest phases, e.g. MIS 2 (Lipecki and Wojtal, 2015; Ersmark et al., 2019; Marciszak et al., 2019a, b).

However, even among dominant large carnivores, levels of local competition were so high that it resulted in a marginal role or even almost total absence of one of the competitors. For example, a revision of more than 50 sites in the Sudetes Mts showed a total absence of the cave hyena; most probably it was outcompeted by the steppe wolf, particularly common in this area (Marciszak et al., 2016, 2020). Climatic conditions also had a very strong impact, as which is documented by deposits dated to MIS 5b-5a. Arid and cold glacial conditions meant that the Central European mainland housed the "standard" herbivore guild of the mammoth steppe with Mammuthus primigenius, Coleodonta antiquitatis, Equus ferus (large form), 

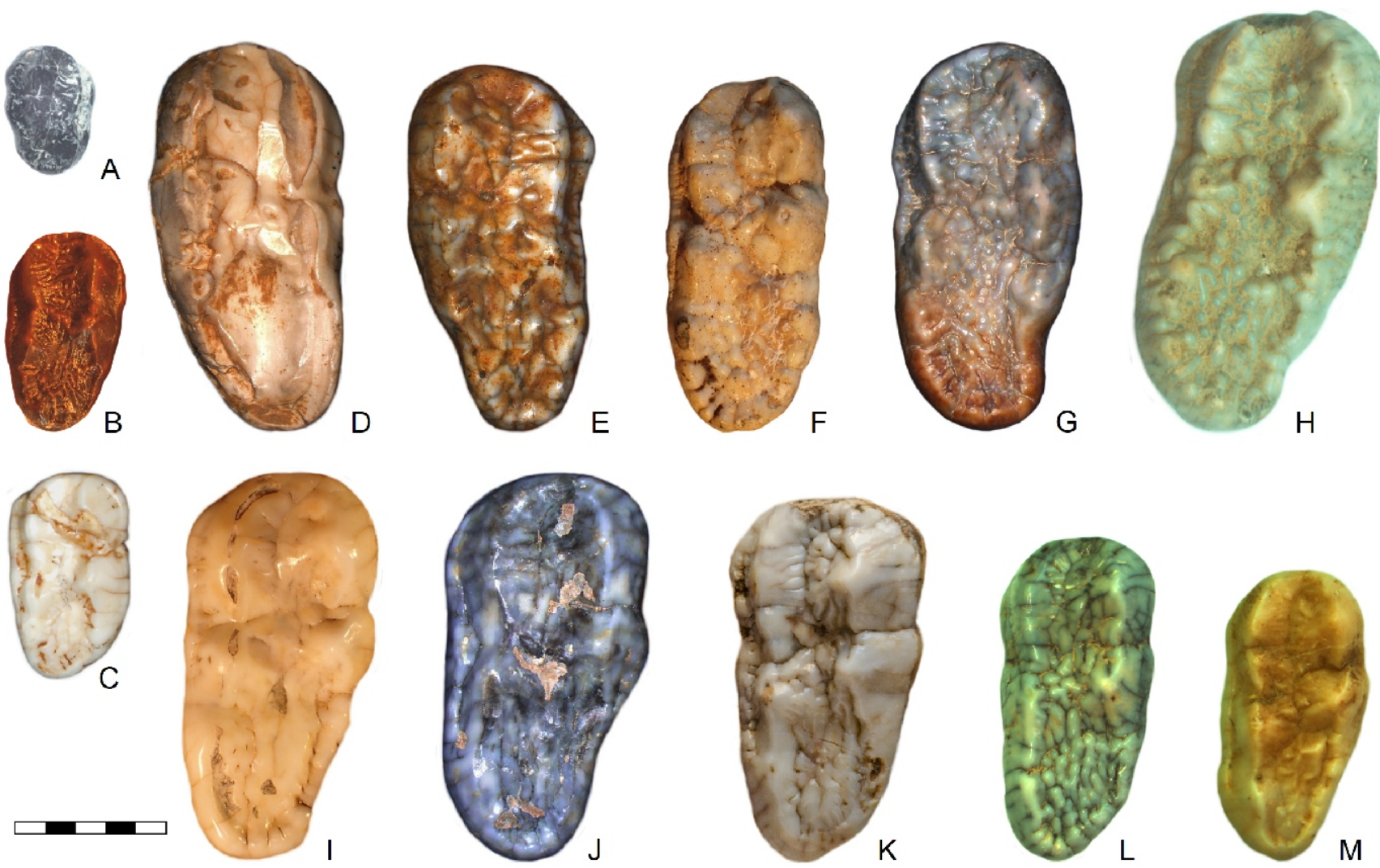

Fig. 4. Comparison of M2 of different bears from Silesia and neighbouring areas

A - Ursavus brevirhinus from Opole 2 (12-11 Ma, ZP UWr/OP2/2); B - Ursus minimus from Węże 1 (3.6-3.2 Ma, coll. no. MZ/177); C - Ursus minimus from Węże 2 (2.4-2.2 Ma, coll. no. ZP UWr/W2/1/1); D - Ursus deningeri from Południowa cave (600-500 ka, coll. no. ZP UWr/JP/4/1); E - Ursus deningeri from Draby 3 (440-400 ka, coll. no. ZPAL M.11/1); F - Ursus rossicus from Naciekowa cave (60-40 ka, ZP UWr/JNW/Us/417); G - Ursus spelaeus spelaeus from Biśnik cave, layer 14 (150-130 ka, coll. no. ZP UWr/JB/Us/12879); H - Ursus ingressus from Biśnik cave, layer 14 (150-130 ka, coll. no. ZP UWr/JB/Us/12879); I - Ursus arctos priscus from Południowa cave (600-500 ka, coll. no. ZP UWr/JP/5/1); J - Ursus arctos priscus from Draby 8 (440-400 ka, coll. no. ZP UWr/D8/5/1); K - Ursus arctos priscus from Kraków-Spadzista (28.8-28.1 ka, coll. no. ISEA MF/7127); L - Ursus arctos cf. arctos from Biśnik cave, layer 1 (14.7-14.2 ka, coll. no. ZP UWr/JB/Ua/14); M - Ursus arctos arctos from Biśnik cave, layer 1ab (3.4-3.2 ka, coll. no. ZP UWr/JB/Ua/14); all teeth showed in occlusal view, scale bar $20 \mathrm{~mm}$

Megaloceros giganteus, Ovibos moschatus, Rangifer tarandus, and Bison priscus. Thermophilous and forest species, such as Palaeoloxodon antiquus, Alces alces, Cervus elaphus, Equus ferus (small form), Bos primigenius, Bison bonasus, and Saiga tatarica disappeared or occurred in particular, restricted short time periods. The carnivore guild was also strikingly different. Only the large steppe wolf and above-mentioned gigantic steppe brown bear are recorded more commonly, while the cave lion and cave hyena, if present, are found in very low numbers and densities. Preliminary analysis of the teeth of $C$. I. spelaeus and partially of $U$. a. priscus showed some heightened level of durophagy, and suggested they expanded into the niche of the absent cave hyena. Similarly, the presence of $U$. $a$. priscus with highly worn teeth suggested they were primarily bone- and frozen carcass-eating scavengers. At this time, there was an atypical situation in Sudetenland, where a relatively narrow carnivore guild (steppe wolf, steppe brown bear, wolverine, and cave lion) focused on rich herbivore pickings. The fearsome and immense steppe brown bear became so large that in the past their remains were misidentified as cave bear, and it was rather formidable kleptoparasite rather than active hunter (Fig. 5; Marciszak et al., 2016; Musil, 2018; Marciszak et al., 2019a, b, 2020).

$U$. a. priscus was well-adapted for survival in the Late Pleistocene of Europe, but its size may have been linked to the cli- mate and environmental conditions. Warming at the beginning of MIS 1 caused ice sheet retreat to the north and much of the Europe gradually transformed from arid, grassy steppes into boreal forests. Enormous herds of ungulates such as horses, mammoths, antelopes, steppe bison, rhinoceroses and many other animals, that were adapted to exist in open grasslands, disappeared as forest became predominant over grasslands. The large bear could not obtain enough food to support its massive body, even if it could supplement its diet with plants.

The process and mechanisms of $U$. a. priscus disappearance are still not resolved. It is possible that it became extinct because of competition with other predators due to their greater ecological plasticity. A more reliable scenario was that some populations retreated east- and northwards. The compact geographical range was split into isolated populations which survived across Europe. Size decrease took place, and $U$. a. priscus evolved into a more herbivorous form due to environmental changes (Fig. 6). Leftovers blended into an abundant nominative form which was much more herbivorous and omnivorous, and so well-adapted to forest conditions. Survival of $U$. a. priscus until the early part of MIS 1 is confirmed by many findings of the great brown bear with particularly large and broad teeth, similar to those in $U$. a. priscus. Such finds are quite common in deposits of the Late Glacial and postglacial periods, in Denmark (Degerbèl, 1933), Germany (Freudenberg, 1914; 


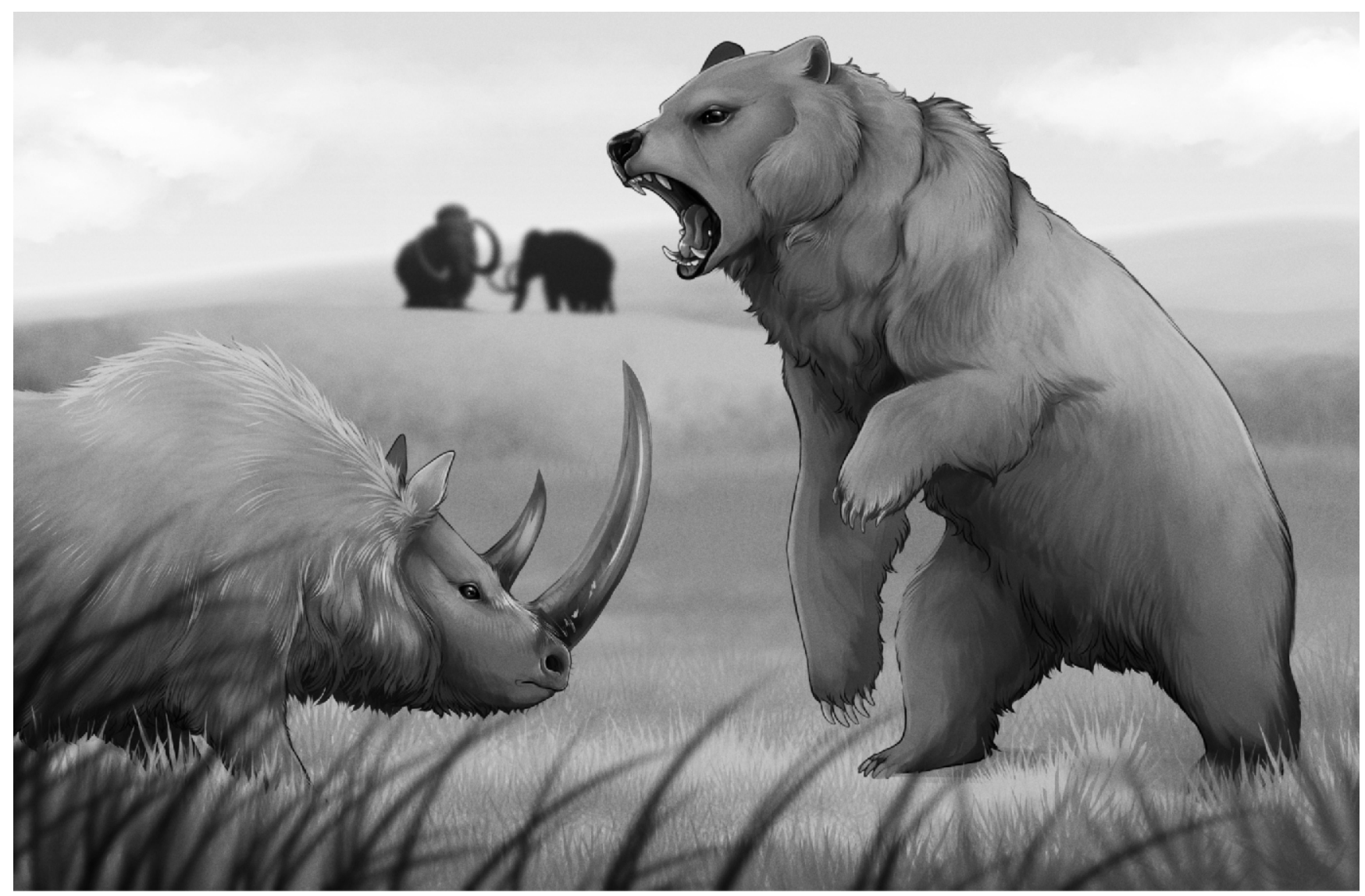

Fig. 5. Conflict scene between female of Coelodonta antiquitatis and male of Ursus arctos priscus in Skarszyn (Trzebnickie Hills)

Such interactions were however very rare and usually ended in a show of strength. Its size, extremely thick skin and long, sharp horns caused that the adult woolly rhino was out of reach of almost all Late Pleistocene carnivores. On the other hand, the steppe brown bear was most likely a scavenger and kleptoparasite. Its immense posture and great size were used to intimidate other carnivores and take their carcasses rather that hunt down big prey like rhino or bison. Drawing by W. Gornig

Hilzheimer, 1939), Great Britain (Adams, 1880; Reynolds, 1906), Ireland (Ball and Owen, 1850), Poland (Müller, 1872; Hilzheimer, 1937; Ruprecht, 1965, 1992), the Netherlands (Erdbrink, 1953, 1967), Russia (Müller, 1872; Vereshchagin, 1959; Baryshnikov and Boeskorov, 2004; Baryshnikov, 2007) and Ukraine (Pidoplichko, 1956). The presence of these large brown bears during the postglacial period of Eurasia should be regarded as a relict survival (Baryshnikov, 2007).

Over the last several thousand years, progressive development of settlements, deforestation and domestic animal breeding slowly but systematically caused a decrease in the density and population of $U$. a. arctos. However, given the low population density, the extent of forest areas and a large number of mountain areas, difficult to access by humans and not suitable for cultivation, this species was quite commonly found throughout Silesia until the end of the Middle Ages (Pax, 1921, 1925, 1937, 1955). Archaeological research show that it inhabited almost all of Silesia between the 14th and the 16th centuries, and its presence has been noted in 29 archaeological Silesian sites (Wyrost, 1994; Marciszak et al., 2020). Old chronicles also mention multiple records of this animal in the lowlands and mountains of this region (Jakubiec, 2001). Besides, archaeological and palaeontological data supported by direct radiocarbon $\left(\mathrm{C}^{14}\right)$ dating document, the presence of $U$. a. arctos in Nowy Targ in Wrocław and in rock shelters on Miłek Mt (Kaczawskie Mts) between 1600 and 1650 has been recorded (Appendix 2).
From the turn of the Middle Ages and modern times, permanent destruction of the environment and extermination increased, and the 1600-1750's were a time of progressive decline in population and population density of $U$. a. arctos in Silesia until its disappearance in the mid-18th century. During this period, hunting descriptions were a sporadic topic in hunting chronicles. Records of hunting by the Schaffgotsch and Tschernin families show a constant presence of the bear until the end of the 18th century. At the same time, however, the number of animals killed clearly shows a decline in this species (Pax, 1921, 1925, 1937; Jakubiec, 2001). This species later disappeared as a breeding population in Silesia, although migrating individuals were recorded until the end of the $18^{\text {th }}$ century. In addition, since the Silesian Wars this region has passed from Austrian rule into Prussian, which resulted in further adverse changes to the bear habitat; the Sudetes became its last refugee. Massive deforestation of the lower stream forests (Sudetes bank forests) began and replacement by spruce monocultures. Similarly, in the Silesian Lowlands, pine was planted in the place of felled deciduous and mixed forests. Settlements increased significantly which, combined with the progressive expansion of agricultural crops and breeding of domestic animals, resulted in a gradual reduction of the space for bears. The Prussian method of rationalizing forest life projected total interference and reconstruction of the food chain. In this scheme, there was no place for carnivores, and thus for a brown bear. Individuals shot in lowland areas were migrating individuals. The Sudetes (and mountains as well) remained the 

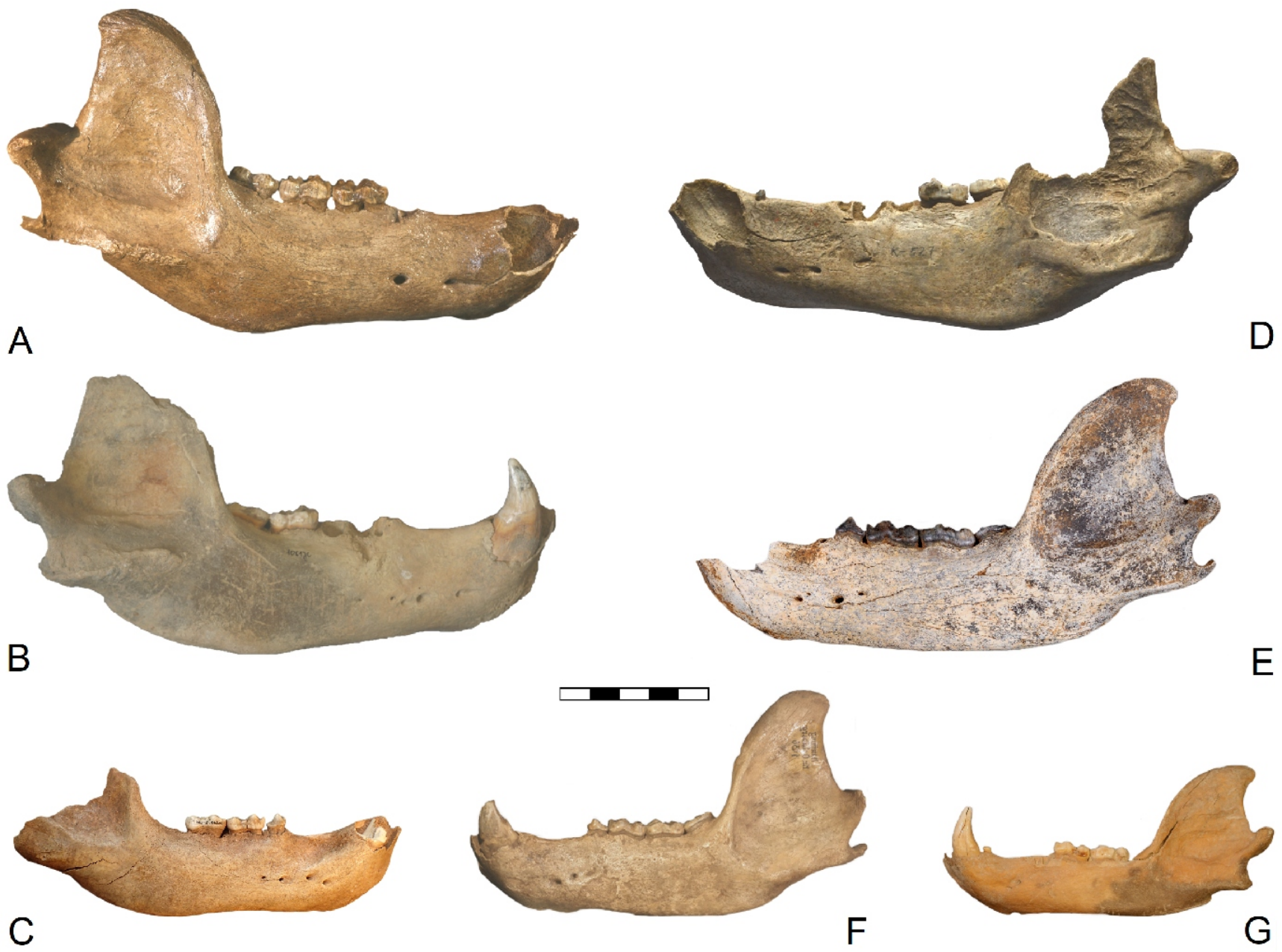

Fig. 6. Mandibles of arctoid and spelaeoid bears from Silesia and neighbouring areas

A - Ursus spelaeus spelaeus (>) from Biśnik cave, layer 14 (180-130 ka, coll. no. ZP UWr/JB/Us/144); B - Ursus ingressus (>) from Ciemna cave, layer 2 (35-25 ka, coll. no. ISEZ JC/1061); C - Ursus rossicus (>) from Naciekowa cave (60-40 ka, coll. no. JZP UWr/JNW/Us/12); D Ursus arctos priscus (>) from Niedźwiedzia cave (>) (60-50 ka, coll. no. ZP UWr/JNK/Ua/1); E - Ursus arctos priscus (>) from Imbramowice (>) (130-115 ka, coll. no. M.1); F - Ursus arctos arctos (>) from Wschodnia cave, Poland (14.3-13.2 ka, coll. no. MMW/I/A/3927); G - Ursus arctos arctos (+) from cave no. 3 on Birów Hill, Poland (4.3-4.1 ka, coll. no. ZP UWr/C3/Ua/2); all mandibles showed in buccal view, scale bar $100 \mathrm{~mm}$

place of their last occurrence. In Sudetes Mts, the last individual was killed in the mid-19th century. However, the last Sudetes brown bears were only individuals, which came from the Czech side from Jesenik and from the Carpathians (Jakubiec, 2001; Flousek et al., 2014).

After the final disappearance of the species in the mid- $18^{\text {th }}$ century to the mid-19th century, individuals migrating from the Carpathians in Jesenik were observed and even hunted (Jakubiec and Buchalczyk, 1987; Jakubiec, 2001; Flousek et al., 2014). For the next 140 years there were no documented bear occurrence in the Sudety Mts. It is possible that there were some individuals, but the chronicles are silent about such cases. No incidental capture, shooting or sighting of the bear was recorded at that time. Considering the degree of penetration and industrialization of the Sudetes, and their use by tourists, it seems unlikely that any bear would escape human attention. It was not until 1991-1998 when bear traces were found in the Polish Sudetes area (Jakubiec, 1995, 1996). When this bear eventually left the Sudetes, over the next 20 years several unconfirmed observations of this species were made, near places such as Wałbrzych, Ludwikowice Kłodzkie and Głuszyca (Červený et al., 2004; Flousek et al., 2014).

\section{MIDDLE PLEISTOCENE-HOLOCENE (700 ka - PRESENT) \\ Ursus ex gr. deningeri-spelaeus}

The taxonomy of the European deningeroid bears has been reviewed by Bishop (1982), Kurtén and Poulianos (1977), Wagner (2010), Wagner and Čermak (2012) and others. In the past most authors recognised a number of species or different forms that seemed to reflect distinct stages in a progressively evolving lineage which is characterized by gradual changes in dental morphology and body size (Partfitt, 1999). Three subspecies of $U$. deningeri are recognised: Ursus deningeri savini (Andrews, 1922) in Britain and Ursus deningeri suevicus Koby, 1952 in continental Europe, from the latest Early and early Middle Pleistocene, and Ursus deningeri deningeri (von Reichenau, 1904) which existed in the mid and late Middle Pleistocene. Two these subspecies are similar in dental morphology, and U. d. suevicus is considered less evolved than U.d. deningeri. Some of the observed differences may have been due to geographical rather than to temporal and/or phyletic variability.

The mid-Middle Pleistocene (MIS 16-13) is a typical level for U. deningeri, with sites like Mosbach 2 (von Reichenau, 1904), 
Hundsheim (Zapfe, 1948), Erpfingen 4 (Heller, 1975), La Romieu (Prat and Thibault, 1976), Cueva Mayor (García, 2003), Château (Argant and Argant, 2002), Westbury (Bishop, 1982), Mauer (von Reichenau, 1906), Isernia la Pineta (Azzaroli et al., 1986), and Petralona (Kurtén and Poulianos, 1981, Tsoukala, 1991).

$U$. deningeri continued uninterrupted to the late Middle Pleistocene and it was characterized by an increase of body size and cheek-teeth complexity (Wagner, 2010). From this period this species is recorded from Draby 2, 3, and 5, and the lowermost layers (19ad-18) of the Biśnik cave dated to MIS 10-8 (Marciszak et al., 2011). Since the bears of spelaeoid lineage appeared in layer 15 (MIS 7) and in the younger layers of the Biśnik cave, this is their oldest record in the Silesian area and entire modern territory of Poland. The evolution of spelaeoid bears from a deningeroid forerunner is differently dated at European sites, with the earliest appearance of $U$. spelaeus s. I. noted from the English site Swanscombe already during MIS 11 (Kurtén, 1959). However, the appearance of this species over most of Europe took place later, and generally it is accepted that $U$. spelaeus s. I. appeared in MIS 7 (Hilpert, 2006).

The cave bear $U$. spelaeus s. I. was an obligate herbivore and one of the most widespread large mammals in the Late Pleistocene in Europe (Hofreiter et al., 2002; Rabeder et al., 2004a, b; Baca et al., 2016). The two main European forms, $U$. s. spelaeus and $U$. ingressus separated probably between 420 and $180 \mathrm{ka}$ (Knapp et al., 2009). U. s. spelaeus lived mainly in Western Europe, although it has also been recorded in the Altai region (Rabeder et al., 2004b; Knapp et al., 2009; Baca et al., 2017), while $U$. ingressus inhabited mostly south-eastern and Central Europe (Rabeder et al., 2004b; Baca et al., 2014).

The geographic origin of $U$. ingressus is still not known, but the basal position of haplotypes from the Romanian site Peştera cu Oase in the phylogeny of this species points to SE Europe (Baca et al., 2012). The phylogeographic picture of $U$. ingressus is unclear as the mtDNA phylogeny lacks significant support and clear phylogeographic lineages cannot be differentiated. Most probably the spread of $U$. ingressus may have proceeded independently along the main European mountain ranges, the Alps and the Carpathians (Baca et al., 2014, 2017).

Previous research suggested that between 60 and $50 \mathrm{ka}$ $U$. ingressus started its migration westwards along the Alps (Hofreiter et al., 2004; Rabeder and Hofreiter, 2004; Münzel et al., 2011). This opinion was based on the earliest and westernmost records of this species from the Austrian and Swiss Alps, dated to $\sim 50 \mathrm{ka}$ (Rabeder and Hofreiter, 2004). However, more recent data showed that some spelaeoid bears from the Polish Jura yielded mtDNA haplotypes identical to those found in $U$. ingressus from the Alps. This may suggest that the population from Eastern and SE Europe spread northwards beyond the Carpathian Arc (Popović et al., 2015; Baca et al., 2017).

According to some researchers, the arrival of $U$. ingressus was associated with the vanishing of other cave bear forms that inhabited the area. One of such replacements was documented from three caves in the Ach Valley (Germany; Hofreiter et al., 2007; Münzel et al., 2011). The latest records of the native inhabitant in this area, U. s. spelaeus, were dated to $\sim 31.5 \mathrm{ka} \mathrm{BP}$ while the earliest appearance of $U$. ingressus was dated to $36.3 \mathrm{ka}$ BP. Beside this single oldest date, most other specimens were dated to $\sim 32 \mathrm{ka} \mathrm{BP}$. That suggests that the main immigration of $U$. ingressus took place just before the local extinction of $U$. s. spelaeus. A similar replacement was documented in the Austrian site Herdengel cave, where the arrival of $U$. ingressus resulted in the disappearance of $U$. s. eremus. All $U$. s. eremus individuals were dated to $>60 \mathrm{ka} \mathrm{BP}$, whereas all
U. ingressus are younger than $37 \mathrm{ka}$ BP (Stiller et al., 2014). However, this scenario of the replacement of earlier native spelaeoid forms by $U$. ingressus cannot be regarded as a general tendency since there are known cases where different spelaeoid bears co-occurred over a longer period. For example, in two other Austrian caves, Ramesch and Gamssulzen, located $\sim 10 \mathrm{~km}$ from each other, $U$. ingressus lived side by side with U. s. eremus for at least 15 ka (Hofreiter et al., 2004).

Such a replacement has not yet been recorded in Silesia. More interesting is that $U$. ingressus co-occurred with $U$. rossicus in the Kaczawa Mts for a long time, since the youngest date for $U$. rossicus is $\sim 43.5-41.7 \mathrm{ka} \mathrm{BP}$, and it is known that both spelaeoid bears were present in the Kaczawa Mts already from at least $80 \mathrm{ky}$. Dates (radiocarbon and uranium-thorium) suggest the more or less continuous presence of spelaeoid bears in the Sudetes Mts during the Late Pleistocene (Nadachowski et al., 2008; Wojtal et al., 2015; Marciszak et al., 2020). Simultaneously, genetic investigation of individuals from Central Europe (mainly the Czech Republic, Poland, Slovakia and Ukraine) revealed that $U$. ingressus was the single form of cave bear present in this part of Europe (Popović et al., 2015). However, it should be noted that genetic analysis of fossil material from many sites like Biśnik cave failed, and this data has so far not been correlated with morphometric analysis. By contrast with genetic results, morphometric investigations showed the presence of at least three different cave bear chronosubspecies, with the dominance of $U$. ingressus since of 100-90 ka BP (Baca et al., 2014). The mtDNA haplotypes of individuals from the Niedźwiedzia cave formed a divergent cluster on phylogenetic trees, which indicates the early separation and expansion of this population (Baca et al., 2012, 2014, 2017). Similar mtDNA haplotypes have been noted farther west in Zoolithen cave (Stiller et al., 2014).

The timing and causes of the extinction of spelaeoid bears in Silesia and in Eurasia also remain unclear. Radiocarbon dates show that the last cave bears went extinct prior to the Last Glacial Maximum (LGM). In the past it was thought that they disappeared approximately synchronously in different parts of Europe around $\sim 28.5-28 \mathrm{ka}$ at the end of Gl-3 (Hofreiter et al., 2002; Pacher and Stuart, 2009; Bocherens et al., 2014). Paleogenetic analyses showed, however, that this process started much earlier, 50-45 ka (Stiller et al., 2010).

Stiller et al. (2014) proposed that spelaeoid bear populations might have declined from east to west, since most of the samples younger than 30 ka have been found in Western Europe. However, AMS dates obtained over the last few years clearly indicate that this is not true and that late cave bears survived independently in isolated populations in different parts of Europe, even into the middle of the GS-3 stadial. In the context of overwhelming disappearance, some karst regions, something akin to a local refuge, may have provided a suitable microclimate for long survival (Baca et al., 2016). An example of such an area in Silesia is Jura Polska, from where the youngest genetically confirmed cave bears so far come from the Stajnia cave, dated to $\sim 26.1 \mathrm{ka} \mathrm{BP}$ (Baca et al., 2016, 2017). Thus, the extinction time of spelaeoid bears can be estimated to between 27.0 and 24.3 ka BP (Baca et al., 2016, 2017; Mackiewicz et al., 2017).

Although, in general perception, most of the megafaunal elements survived until the end of the Late Pleistocene, detailed study shows that this was not the case. In some areas like in Sudetes Mts this "steppe-tundra fauna" had vanished already between 35 and $30 \mathrm{ka}$, earlier than in other Polish areas such as the Jura Polska. Cave bears did not survive there during the LGM (Mackiewicz et al., 2017). The vanishing of these megafaunal elements is only a small part of a general European 
tendency, and the extinction time coincides with the end of the first megafaunal transition, which started in Greenland interstadials 5 to 7 ( $\mathrm{Gl}-5$ to $\mathrm{Gl}-7$ ), and finished at the beginning of the LGM in northern Europe (Cooper et al., 2015). Therefore, the extinction of most members of the so-called "Sudetan megafauna" represents a much earlier pre-LGM megafaunal disappearance, a few thousand years before their final extinction in areas like Jura Polska. The decline of the spelaeoid bear populations in Europe started between 50 and 45 ka (Stiller et al., 2010), and their final extinction was during the coldest and the longest ( $4 \mathrm{ky})$ stadial GS-3 (27.5-23.5 ka) in the last glacial (Mackiewicz et al., 2017).

Climate cooling could have been the main factor affecting cave bear extinction and retreat of most herbivores from the Sudetes Mts before and during the LGM (Stuart and Lister, 2007; Pacher and Stuart, 2009; Baca et al., 2016). Spelaeoid bears were strict herbivores (Kurtén, 1976; Bocherens et al. 2006; Van Heteren et al., 2009, 2014; Mackiewicz et al., 2010; Krajcarz et al., 2016). As a consequence of the climate deterioration, the quality and availability of plant food in Central Europe, being the crucial component of their diet, had decreased. The temperature drop could also have affected the hibernation period of spelaeoid bears (Rabeder et al., 2000; Mackiewicz et al., 2017), when this animal was more vulnerable to hunting (Bocherens et al., 2011a, b; Münzel et al., 2011; Diedrich, 2014 2017; Nowakowski and Stefaniak, 2015; Wojtal et al., 2015). Among the main factors causing cave bear extinction, changing climate has been proposed (Baca et al., 2016, 2017). Craniodental adaptations (Kurtén, 1976; Mackiewicz et al., 2010; Wiszniowska et al., 2010; van Heteren et al., 2014 Pérez-Ramos et al., 2018, 2020) and stable isotope $\left(\delta^{13} \mathrm{C}, \delta^{15} \mathrm{~N}\right)$ studies show that spelaeoid bears were strictly herbivorous (Bocherens et al., 1994, 1997; Fernández-Mosquera et al., 2001; Münzel et al., 2011; Krajcarz et al., 2016; Bocherens 2019). The climate changes which began after GS-3 caused severe transformations in plant communities around Europe (Helmens, 2014). Vegetation seasons shortened and the availability of high-quality plant material, which seems crucial for the survival of spelaeoid bears, significantly decreased. The dietary habits of these bears did not follow any particular modification during their presence for the last $10 \mathrm{ky}$ in Europe and this ecological niche conservatism may have led to their decline (Bocherens et al., 2014; Baca et al., 2017).

Another crucial factor of extinction was the importance of caves for spelaeoid bears as hibernation sites, for which they had to compete with humans and other carnivores (Turner 2009; Münzel et al., 2011; Diedrich, 2014; Mackiewicz et al. 2017). Particular caves, like Niedźwiedzia cave, might have been inhabited by populations where they were born and formed stable maternal social groups for hibernation, as was found in the case of cave bears from Spain (Fortes et al., 2016). The fidelity to the birth site could decrease the probability of finding a proper hibernation place, in cases where the original cave was already occupied or regularly visited by the main competitors/enemies such as lions, hyenas, wolves, and humans. In this context, is the role of the brown bear is especially interesting, but still not well-studied and understood, since there are known regions where $U$. arctos expanded its range and replaced spelaeoid bears leading to the latter's extinction (Kurtén, 1968; Turner, 2009). Large caves were used by the brown bear relatively rarely, and they usually hibernated near the entrance (Diedrich, 2017). However, U. a. priscus, a giant carnivorous form of the brown bear, occurred (probably also co-occurred) together with $U$. a. arctos during the Late Pleistocene (Marciszak et al., 2019a, b, 2020). The steppe brown bear was ecologically much better adapted to a continental climate than were spelaeoid bears, and could win a competition for food and hibernation sites, especially during the cold and arid phases. Due to its size, comparable to or even exceeding the size of cave bears, it might be regarded as a serious threat to the spelaeoid bears, and together with cave lion and cave wolf as the main carnivores feeding on cave bears. This hypothesis still requires further testing by isotopic studies.

Palaeopathological signs on the teeth and bones are found on many specimens assigned to different species. We suppose that some bone injuries resulted from trauma bite damage caused by other bears or large carnivores (mainly their canines) from inter- or intraspecies conflicts. The mortality of carnivores, especially siblings and cubs, is strongly influenced by accidents like falling rocks or being stuck in narrow passages, illness, hunger (e.g., in spelaeoid bears in cases when they do not accumulate enough fat during the vegetation season), seasonal and accidental floods, which flowed through the cave and drowned sleeping bears, and finally simply through old age. However, equally important was the direct activity of the main large carnivores, P. s. spelaea and C. I. spelaeus. Numerous cave bear bones belonged mostly to cubs and young specimens, less than one year old, but also many bones of adult animals with bite marks, chewing and scratches, are clear indications of predation. One of the most spectacular example is a neurocranium of the young female which holds a few holes, with two main ones on the frontal and right parietal bones (Nowakowski and Stefaniak, 2015). The blurred edges of the external lamellae and sclerotic lines indicate that the cave bear female survived, however probably because of illness caused by these injuries it died in the next few months. They were interpreted as resulting from a very strong bite from the canines of another carnivore (Nowakowski and Stefaniak, 2015). It might have been caused by a fight with another cave bear, as such behaviour is common in modern bears (Erdbrink, 1953). Adult males kill the cubs or juvenile specimens usually by biting their skulls (Matheson, 1942; Vaisfeld and Chestin, 1994). Another possible explanation is an attack by a cave lion, since the hunting specialisation of this species on bears is well-known from nitrogen isotope patterns (Bocherens et al., 2011a). The skull described was found in the Niedźwiedzia cave, where an almost complete skull of Panthera spelaea spelaea of considerable size was also found (Wiszniowska, 1978; Barycka, 2008; Marciszak et al., 2014). The distance between two main holes $(\sim 85 \mathrm{~mm})$ fits well with the canine spacing in the lion specimen. Additionally, the cranium has cut marks, sharp-edged longitudinal scars indicating the use of a sharp-edged tool which was interpreted as the effects of skinning and possible indirect proof of human presence in the cave (Nowakowski and Stefaniak, 2015). However, in our opinion, another explanation is also probable. Recently, when the Siberian tiger Panthera tigris tigris has hunted brown bear, it jumps on a bear from above, and tried to hold its head in its frontal paws, simultaneously biting through its cervical vertebrae (Ognev, 1935; Mazak, 1979, 1981; Kirillova and Tesakov, 2008; Kirillova et al., 2009). During such fights, the tiger's claws usually left sharp-edged longitudinal scars on the bear's head, the same as are observed on the skull of the cave bear female from the Niedźwiedzia cave. It is reasonable to extrapolate such hunting behaviour to the cave lion (Kirillova et al., 2009; Diedrich, 2017).

In addition to environmental and habitat changes, some other factors might have negatively influenced the spelaeoid bears. The direct threat of hunting by humans (Münzel et al., 2011; Wojtal et al., 2015), as well as competition from humans for caves as shelters (Grayson and Delpech, 2003) also had a very strong impact. Mitochondrial genome analyses from several Spanish cave sites revealed that spelaeoid bears, in con- 
trast to $U$. arctos, exhibited strong fidelity to the caves where they were born. Facing growing competition as a result of impact with modern humans and Neanderthals, such homing behaviour might have also contributed to their disappearance. The tendency to come back to the same cave for hibernation may have prevented the colonisation of new areas and made spelaeoid bears more predictable for hunters to find (Fortes et al., 2016; Baca et al., 2017).

Besides the well-established records of $U$. ingressus (Baca et al., 2012, 2014, 2017), abundant material of different forms of spelaeoid bears was also recovered from some caves on Mt. Połom (Marciszak, 2011). Especially rich bone material comes from the Naciekowa cave, where $>7000$ bones have been found; in addition, remains of this species also came from the Wschodnia and probably from the Obok Wschodniej caves. The presence of an atypical population from the Wschodnia cave was already recorded by Zotz (1939); he mentioned the presence of a dwarf race of $U$. spelaeus with many arctoid morphological features. Zotz (1939) interpreted the presence of this form as one of the very last populations of the cave bear, similar to those from the Drachen cave. The material from the Naciekowa cave is characterized by small individuals. Also the morphology, with narrow and simply built premolars and molars (P4 without additional cusps, $\mathrm{m} 2$ and $\mathrm{m} 3$ with a poorly developed, straight talonid) and the gracile metacarpals and metatarsals, clearly distinguish the population from the Naciekowa cave from the large and robust $U$. ingressus from the Niedźwiedzia cave (Marciszak, 2011). Morphologically and in size the small cave bear from the Prołom cave resembles the small Caucasian form called the steppe cave bear U. rossicus (Borissiak, 1930, 1932). Direct dating methods (C14 and UTh) and isotopic analysis are needed to clarify its taxonomic position.

\section{CONCLUSIONS}

Revision of the Silesian bear fauna based on 155 sites, mainly cave and karstic localities, but also archaeological and open-air sites, showed the presence of 13 bear forms and species. These records covered the timespan of the last $16.5 \mathrm{Ma}$; they were divided on five main time groups. The oldest bears, represented by the genera Ballusia and Ursavus, are dated on 16.5-11 Ma, and belonged to stem forms of the subfamily Ursinae. The oldest Silesian bear B. elmenensis was recorded from Przeworno 2, dated to 16-14.5 Ma, while the younger Miocene bears were assigned to the genus Ursavus.

After a break of $6 \mathrm{My}$, the earliest members of the genus Ursus appeared in Pańska Góra at 4.9-4.2 Ma. All known Plio- cene bears belong to the genus Ursus were classified as Ursus minimus, and they represent one or two migration events. Additionally, a single occurrence of Agriotherium insigne was recorded from the Węże 1 site between 3.6-3.2 Ma. For this large carnivorous bear, it was one of the last European occurrences. A few Early Pleistocene bear records are represented by a probable ancestor of the arctoid and spelaeoid bear lineages, $U$. etruscus. The oldest representative of Ursus ex gr. arctos so far recorded, $U$. a. suessenbornensis, is known from the latest Early Pleistocene (1.2-0.9 Ma) fauna C of Zamkowa Dolna cave. A number of other Silesian and Polish records of this form require confirmation. The first occurrence of $U$. deningeri, the oldest taxon of the $U$. ex gr. deningeri-spelaeus lineage, was recorded from the Przymiłowice $C$ site dated to $\sim 700 \mathrm{ka}$. The remains of $U$. deningeri are regularly noted from Middle Pleistocene sites within Silesia.

After the pronounced cold period of MIS 12, when the Scandinavian ice sheet covered almost all of Poland, except of the Sudetes and the Carpathians, the fauna changed considerably. This drastic faunal turnover led to the formation of the pan-Eurasian Mammoth Fauna at $\sim 460 \mathrm{ka} \mathrm{BP}$. That was a time when the very characteristic steppe brown bear Ursus arctos priscus, a special ecomorph adapted to live in open grasslands, appeared among the bear fauna. It survived until the beginning of MIS 1, when the modern $U$. arctos arctos appeared in Silesia and survived to the present day.

$U$. deningeri was the most common bear in the Middle Pleistocene, while the first records of $U$. spelaeus spelaeus appeared from MIS 7; later, from the Late Pleistocene ( 110-100 ka) it was slowly replaced in Silesia by U. ingressus. Spelaeoid bears totally dominated the cave assemblages, and finally vanished between 27 and $24 \mathrm{ka}$. The most probable factors leading these animals to their extinction were environmental turnover exacerbated by climatic changes and human impact.

Acknowledgements. We are very grateful to O. Kovalchuk for linguistic improvement and Alejandro Pérez-Ramos and another anonymous reviewer for their helpful critical comments and suggestions. This work was supported by the National Science Centre of Poland, to Adrian Marciszak under grant entitled "The history of the brown bear Ursus arctos Linnaeus, 1758 evolution in Central Europe as a key to modern species conservation" no. UMO-2015/17/D/ST10/01907. The research was also supported by the Ministry of Science and Higher Education, Poland (project 1076/S/IBŚ/2017) and internal grant for young scientists by the Faculty of Biological Sciences (project no. 0411/2093/18).

\section{REFERENCES}

Adams, A.L., 1880. On the recent and extinct Irish mammals. Scientific Proceedings of the Royal Dublin Society, New Series, 2: 45-86.

Ambros, D., Hilpert, B., Kaulich, B., 2005. Das Windloch bei Sackdilling (Fränkische Alb, Süddeutschland). Lage Forschungsgeschichte, Geologie, Paläontologie und Archäologie. Abhandlungen der Naturhistorischen Gesellschaft Nürnberg, 45: 365-382.

Ambrosetti, P., Bartolomei, G., De Giuli, C., Ficcarelli, G., Torre, D., 1979. La breccia ossifera di Slivia (Aurisina-Sistiana) nel
Carso di Trieste. Bollettino della Società Paleontologica Italiana, 18: 207-220.

Argant, A., 2009. Biochronologie et grands mammifères au pleistocène moyen et supérieur en Europe Occidentale: l'apport des canidés, des ursidés et des carnivores en général. Quaternaire, 20: 467-480.

Argant, A., Argant, J., 2002. Die Bären von Château (Burgund, Frankreich). Abhandlungen zur Karst- und Höhlenkunde, 34: $57-63$. 
Azzaroli, A., Giuli, C.de, Ficcarelli, G., Torre, D., 1986. Mamma succession of the Plio-Pleistocene of Italy. Memorie della Societa Geologica Italiana, 31: 213-218.

Baca, M., Stankovic, A., Stefaniak, K., Marciszak, A., Hofreiter, M., Nadachowski, A., Węgleński, P., Mackiewicz, P., 2012 Genetic analysis of cave bear specimens from Niedźwiedzia Cave, Sudetes, Poland. Paleontologia Electronica, 15

Baca, M., Mackiewicz, P., Stankovic, A., Popović, D., Stefaniak, K., Czarnogórska, K., Nadachowski, A., Gąsiorowski, M., Hercman, H., Wegleński, P., 2014. Ancient DNA and dating of cave bear remains from Niedźwiedzia Cave suggest early appearance of Ursus ingressus in Sudetes. Quaternary International, 339-340: 217-223.

Baca, M., Nadachowski, A., Lipecki, G., Mackiewicz, P., Marciszak, A., Popovič, D., Socha, P., Stefaniak, K., Wojtal, P., 2017. Impact of climatic changes in the Late Pleistocene on migrations and extinctions of mammals in Europe: four case studies. Geological Quarterly, 61 (2): 291-304.

Baca, M., Popović, D., Stefaniak, K., Marciszak, A., Urbanowski, M., Nadachowski, A., Mackiewicz, P., 2016. Retreat and extinction of the Late Pleistocene cave bear (Ursus spelaeus sensu lato). The Science of Nature, 103: 1-17.

Bajgusheva, V.S., Titov, V.V., Tesakov, A.S., 2001. The sequence of Plio-Pleistocene mammal faunas from the south Russian Plain (the Azov Region). Bolletino della Societŕ Paleontologica Italiana, 40: 133-138.

Ballesio, R., 1983. Le gisement Pléistocène supérieur de la grotte de Jaurens á Nespouls, Corrèze, France: les Carnivores (Mammalia, Carnivora). III. Ursidae - Ursus arctos Linnaeus. Nouvelles Archives du Musée d'Histoire Naturelle Lyon, 21 9-43.

Ball, R., Owen, R., 1850. On the skulls of bears found in Ireland. Proceedings of the Royal Irish Academy, 4: 416-420.

Barycka, E., 2008. Middle and late Pleistocene Felidae and Hyaenidae of Poland. Fauna Poloniae, Warszawa.

Baryshnikov, G.F., 2007. Semeystvo medvezhi (Carnivora, Ursidae) (in Russian). Nauka, Sankt-Peterburg.

Baryshnikov, G.F., Boeskorov, G.G., 2004. Skull of the Pleistocene brown bear (Ursus arctos) from Yakutia, Russia. Russian Journal of Theriology, 3: 71-75.

Baryshnikov, G.F., Lavrov, A.V., 2015. Early Miocene bear Ballusia (Carnivora, Ursidae) from locality Khirgis-Nur-I in Mongolia. Proceedings of the Zoological Institute Russian Academy of Science, 319: 341-350.

Berzi, A., 1966. L'orso di Gaville nel Valdarno Superiore. Palaeontographia Italica, 60: 19-32.

Beushausen, L., 1906. Rozwój świata zwierzęcego (in Polish). In: Wszechświat i człowiek. Dzieje badań przyrody i zastosowania jej sił na pożytek narodów (ed. J. Kremer): 439-553 Towarzystwo Akcyjne S. Orgelbranda i Synów, Warszawa.

Bieroński, J., Burdukiewicz, J.M., Wiszniowska, T., 1985. Wyniki nowych badań Jaskini Radochowskiej (in Polish). Śląskie Sprawozdania Archeologiczne, 26: 5-18

Bieroński, J., Socha, P., Stefaniak, K., 2007. Deposits and fauna of the Sudeten caves - the state of research. Studies of the Faculty of Earth Sciences, University of Silesia, 45: 183-201.

Bieroński, J., Burdukiewicz, J.M., Socha, P., Stefaniak, K., Hercman, H., Nadachowski, A., 2009a. Palaeogeographical, archeological and palaeozoological studies in the Radochowska Cave. Studies of the Faculty of Earth Sciences, University of Silesia, 56: 455-475.

Bieroński, J., Socha, P., Stefaniak, K., Hercman, H., Gąsiorowski, M., 2009b. Caves in Rogóżka-origin, sediments and fauna. Studies of the Faculty of Earth Sciences, University of Silesia, 56: 477-489.

Bieroński, J., Stefaniak, K., Hercman, H., Socha, P., Nadachowski, A. 2009c. Palaeogeographical and palaeoecological studies of sediments of the Niedźwiedzia (Bear) Cave in Kletno. Studies of the Faculty of Earth Sciences, University of Silesia, 56: 401-422.
Bishop, M.J., 1982. The mammal fauna of the early Middle Pleistocene cavern infill site of Westbury-sub-Mendip, Somerset. Special Papers in Paleontology, 28: 1-107.

Błaszczyk, H., 1938a. Nowe stanowisko niedźwiedzia jaskiniowego w okolicach Częstochowy (in Polish). Ziemia Częstochowska, 2: 258-260.

Błaszczyk, H., 1938b. Odkrycie nowego stanowiska niedźwiedzia jaskiniowego w okolicach Czestochowy (in Polish). Przyroda i Technika, 17: 38-42.

Bocherens, H. 2019. Isotopic insights on cave bear palaeodiet. Historical Biology, 31: 410-421.

Bocherens, H., Fizet, M., Mariotti, A., 1994. Diet, physiology and ecology of fossil mammals as inferred from stable carbon and nitrogen isotope biogeochemistry: implications for Pleistocene bears. Palaeogeography, Palaeoclimatology, Palaeoecology, 107: 213-225

Bocherens, H., Billiou, D., Patou-Mathis, M., Bonjean, D., Otte, M., Mariotti, A., 1997. Paleobiological implications of the isotopic signatures $(13 \mathrm{C}, 15 \mathrm{~N})$ of fossil mammal collagen in Scladina Cave (Sclayn, Belgium). Quaternary Research, 48: 370-380.

Bocherens, H., Drucker, D.G., Bonjean, D., Bridault, A., Conard, N.J., Cupillard, Ch., Germonpré, M., Höneisen, M., Münzel, S.C., Napierala, H., Patou-Mathis, M., Stephan, E., Uerpmann, H.-P., Ziegler, R., 2011a. Isotopic evidence for dietary ecology of cave lion (Panthera spelaea) in North-Western Europe: Prey choice, competition and implications for extinction. Quaternary International, 245: 249-261.

Bocherens, H., Stiller, M., Hobson, K.A., Pacher, M., Rabeder G., Burns, J.A., Tütken, T., Hofreiter, M., 2011b. Niche partitioning between two sympatric genetically distinct cave bears (Ursus spelaeus and Ursus ingressus) and brown bear (Ursus arctos) from Austria: isotopic evidence from fossil bones. Quaternary International, 245: 238-248.

Bocherens, H., Bridault, A., Drucker, D.G., Hofreiter, M., Münzel, S.C., Stiller, M., van der Plicht, J., 2014. The last of its kind? Radiocarbon, ancient DNA and stable isotope evidence from a late cave bear (Ursus spelaeus Rosenmüller, 1794) from Rochedane (France). Quaternary International, 339-340: 179-188.

Borissiak, A., 1930. Ursus spelaeus rossicus nov. n. (in Russian). Doklady Akademii nauk SSSR, 8: 102-104

Borissiak, A., 1932. Novaya rasa peshchernogo medvedya iz chetvertichnykh otlozheniy Sev. Kavkaza (in Russian). Trudy Paleozoologicheskogo Instituta, 1: 137-201.

Bojarska, K., Selva, N., 2012. Spatial patterns in brown bear Ursus arctos diet: the role of geographical and environmental factors. Mammalian Review, 42: 120-143.

Čermák, S., Tásler, R., 2013. Medvědí jeskyně ve východních Krkonoších (Česká republika), předběžná zpráva (in Czech). Opera Corcontica, 50: 227-233.

Červený, J., Bartošová, D., Anděra, M., Koubek, P., 2004. Současné rozšíření medvěda hnědého (Ursus arctos) v České republice (in Czech). Lynx, 35: 19-26.

Chmielewski, W., 1958. Stanowisko paleolityczne w Dziadowe Skale koło Skarzyc w pow. Zawierciańskim (in Polish). Prace i Materiały Muzeum Archeologicznego i Etnograficznego w Łodzi, Seria Archeologiczna, 3: 5-48.

Chmielewski, W., 1975. Paleolit środkowy i górny (in Polish). In: Prahistoria Ziem Polskich,. 1. Paleolit i Mezolit (eds. W. Chmielewski and W. Hensel): 9-158. Ossolineum, Wrocław-Warszawa-Kraków-Gdańsk.

Chrzanowska, W., 1975. Fosylne i subfosylne szczątki kostne zwierzat z jaskini Zamkowej Dolnej w Olsztynie k. Czestochowy (in Polish). Zeszyty Naukowe Akademii Rolniczej we Wrocławiu, 32: 185-194.

Chrzanowska, W., 1986. Szczątki kostne zwierzęce z wczesnośredniowiecznego stanowiska we Wrocławiu na Ostrowie Tumskim (in Polish). Roczniki Akademii Rolniczej w Poznaniu, 172: 19-43.

Chrzanowska, W., Pospieszny, N., 1975. Knochenreste de Wildlebenden Säugetiere aus den frühmittelalterlichen Städten Opole und Wrocław. Zoologica Poloniae, 24: 329-355. 
Clark, P.U., Archer, D., Pollard, D., Blum, J.D., Rial, J.A., Brovkin, V., Mix, A.C., 2006. The middle Pleistocene transition: characteristics, mechanisms, an implications for long-term changes in atmospheric $\mathrm{pCO}_{2}$. Quaternary Science Reviews, 25: 3150-3184.

Cooper, A., Turney, C., Hughen, K.A., Barry, W., Mcdonald, H.G., Bradshaw, C.J.A., 2015. Abrupt warming events drove Late Pleistocene Holarctic megafaunal turnover. Science Express, 349: 1-8.

Crusafont Pairo, M., Kurtén, B., 1976. Bears and bearsdogs from the Vallesian of the Vallés-Penedés Basin, Spain. Acta Zoologica Fennica, 144: 1-29.

Cyrek, K., Nadachowski, A., Madeyska, T., Bocheński, Z., Tomek, T., Wojtal, P., Miękinia, B., Lipecki, G., Garapich, A., Rzebik-Kowalska, B., Stworzewicz, E., Wolsan, M., Godawa, J., Kościów, R., Fostowicz-Frelik, Ł., Szyndlar, Z., 2000. Excavation in the Deszczowa Cave (Kroczyckie Rocks, Czestochowa Upland, Central Poland). Folia Quaternaria, 71: 5-84.

Czapliński, M., Kaszuba, E., Wąs, G., Żerelik, R., 2007. Historia Śląska (in Polish). Wydawnictwo Uniwersytetu Wrocławskiego, Wrocław.

Czarnowski, S.J., 1901. Jaskinia Okopy Wielka nad Prądnikiem (in Polish). Materiały Antropologiczne, Archeologiczne Etnograficzne, 5: 52-93.

Czarnowski, S.J., 1908. Schronisko w Krzyżowej Skale przy Okopach (in Polish). Rocznik Towarzystwa Przyjaciół Nauk Poznańskiego, 34: 141-151.

Czarnowski, S.J., 1912. Jaskinie i schroniska w Kopcowej Górze (in Polish). Materiały Antropologiczne, Archeologiczne i Etnograficzne, 12: 3-22.

Czarnowski, S.J., 1914. Jaskinie w skałach Ogrojca (in Polish). Pamiętnik Fizjograficzny, 22: 32-48.

Czarnowski, S.J., 1924. Jaskinie i schroniska na Górze Koronnej na lewym brzegu Prądnika pod Ojcowem (in Polish). Prace Materiały Antropologiczne, Archeologiczne i Etnograficzne, 3 : 3-26.

Czarnowski, S.J., 1926. Jaskinie Wąwozu Stodouska na prawym brzegu Prądnika pod Ojcowem (in Polish). Przegląd Archeologiczny, 3: 18-33.

Czyżewska, T., 1957. O niedźwiedziu jaskiniowym z terenów Polski (in Polish). Sprawozdania Wrocławskiego Towarzystwa Nauk, 9: 10.

David, A.l., 1982. Mestonakhozhdeniya i vidovoy sostav tiraspolskogo teriokompleksa na territorii Moldavii (in Russian). In: Problemy antropogena Moldavii (eds. K.N. Negadaev-Nikonov, A.I. David, P.D. Bukatchuk, M.I. Voloshina and A.N. Chubka): 87-108. Štiinca, Kišinev.

de Bonis, L., Abella, J., Merceron, G., Begun, D.R., 2017. A new late Miocene ailuropodine (giant panda) from Rudab'anya (North-central Hungary). Geobios, 50: 413-421.

Degerbøl, M., 1933. Danmarks Pattedyr i Fortiden Sammenligningmed recente Former (in Danish). Videnskabelige Meddelelser fra Dansk Naturhistorisk Forening, 96: 357-641.

Dehm, R., 1950. Die Raubtiereausdem Mittel-Miocän (Burdigalium) von Wintershof-West bei Eichstätt in Bayern. Abhandlungen der Bayerischen Akademie der Wissenschaften, Mathematisch-naturwissenschaftliche Klasse, neue Folge, 58: 1-141.

Delson, E., Thomas, H., Spassov, N., 2005. Fossil Old World monkeys (Primates, Cercopithecidae) from the Pliocene of Dorkovo, Bulgaria. Geodiversitas, 27: 159-166.

Demetrykiewicz, Z., Kuźniar, W., 1914. Najstarszy paleolit na ziemiach polskich oraz inne wykopaliska odkryte w jaskini „Okiennik” (in Polish). Materiały Antropologiczne, Archeologiczne i Etnograficzne, 13: 10-43.

Demidziuk, K., 2012. Archiwalia sprzed 1845 roku po archeologii polskich Sudetów - Góry Kaczawskie w Sudetach Zachodnich (in Polish). Silesia Antiqua, 48: 275-342.

Depéret, C., Llueca, G., 1928. Sur l'Indarctos arctoides et la phylogéne des Ursidés. Bulletin de la Société géologique de France Serie 4, 28: 149-160.
Diakowski, M., Zych, J., 2014. Analiza archeozoologiczna materiału kostnego ze stanowiska Grzybiany (in Polish). In: Osada kultury pól popielnicowych w Grzybianach koło Legnicy (eds. T. Stolarczyk and J. Baron): 335-345. Muzeum Miedzi w Legnicy, Legnica-Wrocław.

Diedrich, C.G., 2014. Holotype skulls, stratigraphy, bone taphonomy and excavation history in the Zoolithen Cave and new theory about Esper's "great deluge". Quaternary Science Journal, 63: 78-98.

Diedrich, C.G., 2017. Famous Planet Earth Caves: Hermann's Cave (Germany). A Late Pleistocene cave bear den. 2. Bentham Books, London.

Ehrenberg, K., 1938. Über einige weitere Ergebnisse der Untersuchungen an den Bären von Winden. Verhandlungen der Zoologisch-Botanischen Gesellschaft in Wien, 86-87: 388-395.

Ehrenberg, K., 1955. Über Höhlenbären- und Bärenhöhlenfragen. Mitteilungen der Höhlenkommission, 2: 54-57.

Erbaeva, M.A., Montuire, S., Chaline, J., 2001. New ochotonids (Lagomorpha) from the Pleistocene of France. Geodiversitas, 23: 395-409.

Erdbrink, D.P., 1953. A review of fossil and recent bears of the Old World; with remarks on their phylogeny, based upon their dentition. Jan de Lange, Deventer.

Erdbrink, D.P., 1967. New finds of fossil bears from the Netherlands. Lutra, 9: 17-41.

Ersmark, E., Baryshnikov, B., Higham, T., Argant, A., Castańos, P., Döppes, D., Gasparik, M., Germonpré, M., Lidén, K., Lipecki, G., Marciszak, A., Miller, R., Moreno García, M., Pacher, M., Robu, M., Rodriguez Varela, R., Rojo Guerra, M., Sabol, M., Spassov, N., Storí, J., Valdiosera, Ch., Villaluenga, A., Stewart, J.R., Dalén, L., 2019. Genetic turnovers and northern survival during the last glacial maximum in European brown bears. Ecology and Evolution, 9: 5891-5905.

Euler, H., 1941. Künstliche "Maulsperrer" beieinem Braunbären der Alsteizeit aus den Höhlen des Kitzelberges. Eine fachliche Anmerkung zu Zotz "Die schlesischen Höhlen und ihre eiszeitlichen Bewöhner”. Altschlesische Blätter, 16: 81-108.

Fejfar, O., 1976. Plio-Pleistocene mammal sequences. In: International geological correlation programme, Project 73/1/24 - Quaternary glaciations in the Northern Hemisphere, Report 3, 1975 (eds. J. Easterbrook and V. Šibrava V): 351-366. Ústřední ústav geologický, Praha.

Fejfar, O., Heinrich, W.-D., 1983. Arvicoliden-Sukzession und Biostratigraphie des Oberpliozäns und Quartärs in Europa. Schriftenreihe für Geologische Wissenschaften, 19-20: 61-109.

Fejfar, O., Heinrich, W.-D., Lindsay, E.H., 1998. Updating the Neogene rodent biochronology in Europe. Mededelingen Nederlands Instituut voor Toegepaste Geowetenschappen TNO, 60: 533-554.

Fernández-Mosquera, D., Vila-Taboada, M., Grandal-d'Anglade, A., 2001. Stable isotopes data $\left(\delta^{13} \mathrm{C}, \delta^{15} \mathrm{~N}\right)$ from the cave bear (Ursus spelaeus): a new approach to its palaeoenvironment and dormancy. Proceedings of the Royal Society B: Biological Sciences, 268: 1159-1164.

Flousek, J., Zając, T., Kutal, M., Żuczkowski, M., Pałucki, A., Pudil, M., Kafka, P., 2014. Velké šelmy (Carnivora) V Krkonoších, Jizerských horách, Górach Stołowych a na Broumovsku (Česká republika, Polsko) - minulost a přítomnost (in Czech). Opera Corcontica, 51: 37-59.

Fortes, G.G., Grandal-d'Anglade, A., Kolbe, B., Fernandes, D., Meleg, I.N., García-Vázquez, A., Pinto-Llona, A.C., Constantin, S., de Torres, T.J., Ortiz, J.E., Frischauf, C., Rabeder, G., Hofreiter, M., Barlow, A., 2016. Ancient DNA reveals differences in behaviour and sociality between brown bears and extinct cave bears. Molecular Ecology, 25 : 4907-4018.

Franzen, J.L., 1999. The late Early Pleistocene teeth and bone accumulation of Dorn-Dürkheim 3 (Germany, Rheinhessen): natural or man-made? Monographien des Römisch-Germanischen Zentralmuseums, 42: 41-56. 
Frech, F., 1904. Lethea geognostica. 3. Teil, 2 Band. Quartar, Stuttgart.

Frenzel, J., 1936. Knochenfunde in der Reyersdorfer Tropsteinhöhle. Beiträge zur Biologie des Glatzer Schneeberges, 2: 121-134.

Frenzel, J., 1937. Die Reyersdorfer Tropsteinhöhle, ein schlesisches Naturdenkmal. Schlesische Heimat, 1: 6-11.

Freudenberg, W., 1914. Die Säugetiere des älteren Quartärs von Mitteleuropa mit besonderer Berücksichtigung der Fauna von Hundsheim und Deutschaltenburg in Niederösterreich etc. Geologische und Paläontologische Abhandlungen, Neue Folge, 12: $1-219$.

Gaillard, C., 1899. Mammifäères miocènes nouveaux ou peu connus de la Grive-Saint-Alban (Isère). Archives du Muséum d'histoire naturelle de Lyon, 7: 1-78.

García, N.G., 2003. Osos y otros carnívoros de la Sierra de Atapuerca. Fundación Oso de Asturias, Oviedo.

García, N., Arsuaga, J.L., 2001. Ursus dolinensis: a new species of Early Pleistocene ursid from Trinchera Dolina, Atapuerca (Spain). Comptes Rendus de l'Académie des Sciences. Série II, Sciences de la Terre et des Plančtes, 332: 717-725.

Gedl, M., 1965. Osada kultury łużyckiej na st. 2 w Kietrzu, pow. Głubczyce (materiały z badań ekspedycji kietrzańskiej w latach 1957-1962) (in Polish). Materiały Archeologiczne, 6: 71-96.

Gervais, P., 1853. Description des ossements fossiles de mammifères rapportés d'Espagne par MM. de Verneuil Collomb et de Lorière. Bulletin de la Société géologique de France 2e série, 10: 147-168.

Gervais, P., 1859a. Zoologie et paléontologie françaises. 2e éd. Arthus Bertrand, Paris.

Gervais, P., 1859b. Sur une nouvelle espèce d'Hipparion découverte auprès de Perpignan. Comptes Rendus de l'Académie des Sciences de Paris, 48: 1117-1118.

Gibbard, P., Cohen, K.M., 2008. Global chronostratigraphical correlation table for the last 2.7 million years. Episode, 31 : 243-247.

Gibbard, P., Head, M.J., 2009a. The definition of the Quaternary system/period and the Pleistocene series/epoch. Quaternaire, 20: 125-133.

Gibbard, P., Head, M.J., 2009b. IUGS ratification of the Quaternary System/Period and the Pleistocene Series/Epoch with a base at 2.58 MA. Quaternaire, 20: 411-412.

Ginsburg, L., Morales, J., 1998. Les Hemicyoninae (Ursidae, Carnivora, Mammalia) et les formes apparentées du Miocéne inférieur et moyen d'Europe occidentale. Annales de Paléontologie, 84: 71-123.

Gliozzi, E., Abbazzi, L., Argenti, P., Azzaroli, A., Caloi, L., Capasso Barbato, L., di Stefano, G., Esu, D., Ficcarelli, G., Girotti, O., Kotsakis, T., Masini, F., Mazza, P., Mezzabotta, C., Palombo, M.R., Petronio, C., Rook, L., Sala, B., Sardella, R., Zanalda, E., Torre, D., 1997. Biochronology of selected mammals, molluscs and ostracods from the Middle Pliocene to the Late Pleistocene in Italy. The state of the art. Rivista Italiana $\mathrm{d}$ Paleontologia e Stratigrafia, 130: 369-388.

Grayson, D.K., Delpech, F., 2003. Ungulates and the Middle-to-Upper Paleolithic transition at Grotte XVI (Dordogne, France). Journal of Archaeological Science, 30: 1633-1648.

Gretzinger, J., Molak, M., Reiter, E., Pfrengle, S., Urban, Ch. Neukamm, J., Blant, M., Conard J., Cupillard, N.J., Dimitrijević, V.G., Drucker, D.G., Hofman-Kamińska, E., Kowalczyk, R., Krajcarz, M.T., Krajcarz, M., Münzel, S.C., Peresani, M., Romandini, M., Rufí, I., Soler, J., Terlato, G Krause, J., Bocherens, H., Schuenemann, V.J., 2019 Large-scale mitogenomic analysis of the phylogeography of the Late Pleistocene cave bear. Scientific Reports, 9: 10700.

Gürich, G., 1885. Quartärfauna von Schlesien. Jahresbericht der Schlesischen Gesellschaft für Vaterländische Kultur, 62 261-270.

Gürich, G., 1890. Erläuterungen zu der Geologischen Uebersichtskarte von Schlesien. J. U. Kern's Verlag, Breslau.

Heinevetter, F., 1933. Die Oberschlesien Diluvialfunde der Jahre 1932/33. Jahresbericht des Geologischen Vereins Oberschlesiens, 1933: 49-50.
Heinevetter, F., 1937. Die eiszeitlichen Funde in Gebiet von Glewitz. Jahresbericht des Geologischen Vereins Oberschlesiens, 1937: 38-40.

Helbing, H., 1932. Über einen Indarctos-Schädel aus dem Pontien der Insel Samos. Nebst einem Anhang: Hyaenarctos spec. Aus dem Pliocaen von Vialette (Haute-Loire). Abhandlungen der Schweizerischen Palaeontologischen Gesellschaft, 52: 1-18.

Helbing, H., 1936. Die Carnivoren des Steinheimer Beckens. A. Mustelidae. Palaeontographica, 8: 1-56.

Heller, F., 1975. Ein neuer Vertreter des Ursus deningeriFormkreises aus der altquartären Wirbeltierfauna von Erpfingen (Schwäbische Alb). Mitteilungen aus dem GeologischPaläontologischen Institut der Universität Hamburg, 44: 111-122.

Helmens, K.F., 2014. The last interglacial-glacial cycle (MIS 5-2) re-examined based on long proxy records from central and northern Europe. Quaternary Science Reviews, 86: 115-123.

Hendey, Q.B., 1972. Pliocene ursids from South Africa. Annales of the South African Museum, 59: 115-132.

Hendey, Q.B., 1974. The late Cenozoic Carnivora of the southwestern Cape Province. Annals of the South African Museum, 63 $1-369$.

Hensel, R., 1852. Über die fossilen Säugethiere Schlesiens. Jahresbericht der Schlesischen Gesellschaft für Vaterländische Kultur, 30: 37-38.

Hensel, R., 1853. Übersicht der fossilen und lebenden Säugethiere Schlesiens. Jahresbericht der Schlesischen Gesellschaft für Vaterländische Kultur, 32: 239-250.

Herr, O., 1924. Diluviale und altalluviale Säugetierreste aus der Oberlausitz. Abhandlungen der Naturforschenden Gesellschaft zu Görlitz, 29: 92-101.

Hilpert, B., 2006. Die Ursiden aus Hunas - Revision und Neubearbeitung der Bärenfunde aus der Steinberg-Höhlenruine bei Hunas (Gde. Pommelsbrunn, Mittelfranken, Bayern). Master Thesis, Friedrich-Alexander-Universität, Erlangen.

Hilzheimer, M., 1937. Ein Braunbärenschädel aus der Neumark. Märkische Tierwelt, 3: 42-52.

Hilzheimer, M., 1939. Ein zweiter Braunbärenschädel aus der Mark. Märkische Tierwelt, 4: 60-62.

Hofmann, A., 1887. Über einige Säugetierreste aus dem Braunkohle von Voitsberg und Steieregg bei Wies, Steiermark. Jahrbuch der Kaiserlich-Königlichen Geologischen Reichsanstalt, 37: 207-218.

Hofmann, A., 1892. Beiträe zur miocaenen Säugetierfauna der Steiermark. Jahrbuch der Kaiserlich-Königlichen Geologischen Reichsanstalt, 42: 63-76.

Hofreiter, M., Capelli, C., Krings, M., Waits, L., Conard, N., Münzel, S., Rabeder, G., Nagel, D., Paunovic, M., Jambresić, G., Meyer, S., Weiss, G., Pääbo, S., 2002. Ancient DNA analyses reveal high mitochondrial DNA sequence diversity and parallel morphological evolution of Late Pleistocene cave bears. Molecular Biology and Evolution, 19: 1244-1250.

Hofreiter, M., Rabeder, G., Jaenicke-Després, V., Withalm, G., Nagel, D., Paunovic, M., Jambresić, G., Pääbo, S., 2004. Evidence for reproductive isolation between Cave Bear populations. Current Biology, 14: 40-43.

Horáček, I., Ložek, V., 1988. Palaeozoology and the Mid-European Quaternary past: scope of the approach and selected results. Rozpravy Česká akademie věd a umění, Matematické a Přírodní Vědy, 98: 1-102.

Hoyer, H.F., 1923. Zwierzęta kopalne okolic Krakowa (in Polish). Ziemia, 8: 118-122.

Hoyer, H.F., 1937. Fauna dyluwialna Polski (in Polish). Kosmos, 62 : 181-210.

Jakubiec, Z. 1995. Niedźwiedź wrócił w Sudety (in Polish). Chrońmy Przyrodę Ojczystą, 51: 91-93.

Jakubiec, Z. 1996. Stwierdzenia niedźwiedzia brunatnego Ursus arctos w północno-wschodniej Polsce (in Polish). Chrońmy Przyrodę Ojczystą, 52: 105-107.

Jakubiec, Z. 2001. Niedźwiedź brunatny Ursus arctos L. w polskiej części Karpat (in Polish). Studia Naturae, 47: 1-108. 
Jakubiec, Z., Buchalczyk, T., 1987. The brown bear in Poland: its history and present numbers. Acta Theriologica, 32: 289-306.

Jánossy, D., 1963. Die altpleistozäne Wirbeltierfauna von Kövesvárad bei Répáshuta (Bükk-Gebirge). Annales Historico-Naturales Musei Nationalis Hungarici, Pars Mineralogica et Palaeontologica, 55: 109-141.

Jánossy, D., 1978. Larger mammals from the lowermost Pleistocene fauna Osztramos, Loc. 7. (Hungary). Annales Historico-Naturales Musei Nationalis Hungarici, 70: 69-79.

Qigao, J., Flynn, J.J., 2019. A new species of Agriotherium from North America, and implications for understanding transformations in the metaconid-entoconid complex of bears. Journal of Mammalian Evolution, https://doi.org/10.1007/s10914-019-09480-x.

Kahlke, R.-D., 2014. The origin of Eurasian Mammoth faunas (Mammuthus-Coelodonta Faunal Complex). Quaternary Science Reviews, 96: 32-49.

Kahlke, R.-D., Garcia, N., Kostopoulos, D.S., Lacombat, F., Lister, A.M., Mazza, P.P.A., Spassov, N., Titov, V.V., 2011. Western Palaearctic palaeoenvironment conditions during communities, and implications for hominin dispersal in Europe. Quaternary Science Review, 30: 1368-1395.

Kahlke, R.-D., Lacombat, F., 2008. The earliest immigration of woolly rhinoceros (Coelodonta tologoijensis, Rhinocerotidae, Mammalia) into Europe and its adaptive evolution in Palaearctic cold stage mammal faunas. Quaternary Science Reviews, 27: 1951-1961.

Kirkor, A.H., 1879. Sprawozdanie z poszukiwań w grocie Lisionki pod Czerną (in Polish). Zbiór Wiadomosci do Antropologii Krajowej, 3: 8-12.

Kirillova, I.V., Tesakov, A.S., 2008. New mammalian elements of the Ice Age assemblage on the Sakhalin Island Ice Age mammals from Sakhalin. Mammal Study, 33: 87-92.

Kirillova, I.V., Zelenkov, N., Tesakov, A.S., 2009. Master and visitors of the cave Ostantsevaya (Sakhalin Island, Russian Far East). Acta Carstologica Slovaca, 47: 57-66.

Klaatsch, H., 1906. Powstanie i rozwój rodu ludzkiego (in Polish). In: Wszechświat i Człowiek. Dzieje badań przyrody zastosowania jej sił na pożytek narodów (ed. J. Kremer): 3-365. Towarzystwo Akcyjne S. Orgelbranda i Synów, Warszawa.

Knapp, M., Rohland, N., Weinstock, J., Baryshnikov, G.F., Sher, A., Nagel, D., Rabeder, G., Pinhasi, R., Schmidt, H.A., Hofreiter, M., 2009. First DNA sequences from Asian cave bear fossils reveal deep divergences and complex phylogeographic patterns. Molecular Ecology, 18: 1225-1238.

Koby, F.-E., 1952. Un noveau gisement ŕ Ursus deningeri von Reich. Eclogae Geologicae Helvetiae, 44: 398-403.

Koenigswald, R.V., 1925. Beitrag zur Kenntnis der Gattung Ursavus in Schwaben. Zentralblatt für Mineralogie, Geologie und Paläontologie, Abteilung B: Paläontologie, 1925: 16-20.

Koenigswald, R.V., Tobien, H., 1987. Bemerkungen zur Altersstellung der pleistozänen Mosbach-Sande bei Wiesbaden. Geologische Jahrbücher Hessen, 115: 227-237.

Koken, E., 1888. Ueber die miocänen Säugethier-Reste von Kieferstädtl in Oberschlesien und über Hyaenarctos minutus Schlosser. Sitzungsberichte der Gesellschaft Naturforschender Freunde zu Berlin, 1888: 44-49.

Kopacz, J., Skalski, A.W., 1976. Excavations of the cave system in the Towarne Mountains near Czestochowa. Archeologia Polonica, 17: 163-175.

Koppers, W., 1933. Der Bärenkult in ethnologischer und prähistorischer Beleuchtung. Palaeobiologica, 5: 47-64.

Koppers, W., 1938. Künstlicher Zahnschliffam Bären im Altpaläolithikum und bei den Ainu auf Sachalin. Quartär, 1: 97-103.

Kormos, T., 1937. Zur Geschichte und Geologie der oberpliozänen Knochenbreccien des Villányer Gebirges. Mathematischer und Naturwissenschaftlicher Anzeiger, 56: 1063-1100.

Korotkevič, M.L., 1967. Fauna krupnykh mlekopitayushchikh iz pliotsenovykh otlozheniy doliny r. Kychurgana. In: Mesto i znacheniye iskopayemykh mlekopitayushchikh Moldavii v kaynozoye SSSR: 77-84. Shiinca, Kishinev.
Kowalski, K., 1951. Jaskinie Polski (in Polish), 1. Państwowe Muzeum Archeologiczne, Warszawa.

Kowalski, K., 1954. Jaskinie Polski (in Polish), 3, Jaskinie Pienińskiego Pasma Skalic, Beskidów i Pogórza Karpackiego, Sudetów, Niecki Nidziańskiej, Gór Świętokrzyskich, Pomorza. Państwowe Wydawnictwo Naukowe, Warszawa.

Kowalski, K., 1959. Katalog ssaków plejstocenu Polski (in Polish). Państwowe Wydawnictwo Naukowe, Warszawa.

Kowalski, K., 1989a. Historia i ewolucja lądowej fauny Polski (red.). Folia Quaternaria, 59-60: 1-276.

Kowalski, K., 1989b. Podsumowanie (in Polish). Folia Quaternaria, 59-60: 247-263.

Kowalski, K., 1990. Stratigraphy of Neogene mammals of Poland In: European Neogene mammal chronology (eds. E.H. Lindsay, V. Fahlbusch and P. Mein): 193-209. Plenum Press, New York.

Kowalski, K., Rzebik-Kowalska, B., 2002. Paleoecology of the Miocene fossil mammal fauna from Bełchatow (Poland). Acta Theriologica, Supplement 1, 47: 115-126.

Kozłowski, L., 1922. Starsza epoka kamienna w Polsce (in Polish). Prace Komisji Archiwalnej Poznańskiego Towarzystwa Przyjaciół Nauk, 1: 1-53.

Kozłowski, L., 1924. Die ältere Steinzeit in Polen. Die Eiszeit, 1: 112-163.

Krajcarz, M.T., Pacher, M., Krajcarz, M., Laughlam, L., Rabeder, G., Sabol, M., Wojtal, P., Bocherens, H., 2016. Isotopic variability of cave bears $\left(\delta^{15} \mathrm{~N}, \delta^{13} \mathrm{C}\right)$ across Europe during MIS 3. Quaternary Science Reviews, 131: 51-72.

Kretzoi, M., 1938. Die Raubtiere von Gombaszög nebst einer Übersicht der Gesamtfauna. Annales Musei Nationalis Hungarici, Pars Mineralogica, Geologica et Palaeontologica, 31: 88-157.

Kretzoi, M., 1954. Bericht über die calabrische (villafranchische) Fauna von Kislang, Kom. Fejér. Jahresbericht der Ungarischen Geologischen Anstalt, 1953: 239-265.

Krukowski, S., 1921. Badania jaskiń pasma KrakowskoWieluńskiego w r. 1914 (in Polish). Archiwum Nauk Warszawskiego Antropologicznego Towarzystwa Naukowego, 1: $1-8$.

Krukowski, S., 1939. Paleolit (in Polish). Prehistoria Ziem Polskich, Kraków, 4, cz. 1.

Krysiak, K., 1956. Szczątki zwierzęce ze schroniska skalnego pod Podlesicami w pow. zawierciańskim (in Polish). Prace i Materialy Muzeum Archeologicznego i Etnograficznego w Łodzi, Seria Archeologia, 1: 41-47.

Kubasiewicz, M., 1963. Szczątki zwierzęce z wczesnośredniowiecznego grodziska w Sieradzu (in Polish). Prace i Materiały Muzeum Archeologicznego i Etnograficznego w Łodzi, 9: 195-233.

Kubasiewicz, M., Gawlikowski, J., 1976. Szczątki zwierzęce z osady łużyckiej Grodziec, pow. Będzin (in Polish). Roczniki Muzeum Okręgowego w Częstochowie 4, Archeologia I, 1976: 107-129.

Kurtén, B., 1956. The bears and hyenas of the interglacials. Quaternaria, 4: 1-13.

Kurtén, B., 1959. On the bears of the Holsteinian Interglacial. Stockholm Contributions in Geology, 2: 73-102.

Kurtén, B., 1967. Pleistocene bears of North America, II: Genus Arctodus, short-faced bears. Acta Zoologici Fennici, 117: 1-60.

Kurtén, B., 1968. Pleistocene mammals of Europe. Weidenfeld and Nicolson, London.

Kurtén, B., 1976. The cave bear story: life and death of a vanished animal. Columbia University Press.

Kurtén, B., Poulianos, A.N., 1977. New stratigraphic and faunal material from Petralona Cavewith special reference to the Carnivora. Anthropos, 4: 47-130.

Kurtén, B., Poulianos, A.N., 1981. Fossil Carnivora of Petralona Cave: Status of 1980. Anthropos, 8: 9-56.

Lacombat, F., Abbazzi, L., Ferretti, M.P., Martinez-Navarro, B., Moullé, P.-E., Palombo, M.-R., Rook, L., Turner, A., Valli, A.M.-F., 2008. New data on the Early Villafranchian fauna from Vialette (Haute-Loire, France) based on the collection of the 
Crozatier Museum (Le Puy-en-Velay, Haute-Loire, France) Quaternary International, 179: 64-71.

Lipecki, G., Wojtal, P., 2015. Carnivores from the open-air Gravettian site Kraków Spadzista. In: A Gravettian site in Southern Poland: Kraków Spadzista (eds. J. Wilczyński, P. Wojtal and G Haynes): 117-157. Institute of Systematics and Evolution of Animals, Polish Academy of Science, Kraków.

Longin, R., 1971. New method of collagen extraction for radiocarbon dating. Nature, 230: 241-242.

Lubicz-Niezabitowski, E., 1898. O wyrastaniu ostatniego zęba trzonowego w dolnej szczęce niedźwiedzia jaskiniowego (Ursus spelaeus) (in Polish). Sprawozdanie z czynności i posiedzeń Akaddemii Umiejętności w Krakowie, 3: 12-13.

Lubicz-Niezabitowski, E., 1938. O kilku ciekawszych szczatkach kopalnych zwierząt ssących Polski. Kosmos A, 62: 431-438.

Mackiewicz, P., Socha, P., Stefaniak, K., Marciszak, A., Nadachowski, A., 2017. Estimating the extinction time of two cave bears Ursus spelaeus and U. ingressus. Acta Zoologica Cracoviensia, serie A, Vertebrata, 60: 1-14.

Mackiewicz, P., Wiszniowska, T., Olejniczak, A.J., Stefaniak, K., Socha, P., Nadachowski, A., 2010. Analysis of dental ename thickness in bears with special attention to Ursus spelaeus and $U$. wenzensis (=minimus) in comparison to selected representatives of mammals,. In: Morphology and dystematics of fossil vertebrates (ed. D. Nowakowski): 60-77. DN Publisher, Wrocław.

Madeyska, T., 1981. Le milieu naturel de l'homme du Paleolithique moyen et superieur en Pologne a la lumiere des recherches geologiques (in Polish with French summary). Studia Geologica Polonica, 69: 7-125.

Madrell-Malapeira, J., Alba, D. M., Moyà-Solà, S., 2009. Carnivora from the late Early Pleistocene of Cal Guardiola (Terrassa, Vallès-Penedès Basin, Catalonia, Spain). Journal of Paleontology, 83: 969-974

Maier von Mayerfels, S., 1929. Zur Stammesgeschichte der europäischen Bären. Neues Jahrbuch für Mineralogie, Geologie und Paläontologie, Beilagen, 62: 325-332.

Makowiecka, M. Makowiecki, D. 2006. Studia nad średniowieczna gospodarką zwierzętami w strefie środkowej Odry na podstawie analiz archeozoologicznych materiałów z Krosna Odrzańskiego (in Polish). In: Archeologia w studiach nad najstarszymi dziejam Krosna Odrzańskiego (eds. M. Magda-Nawrocka, M., A Nawojska and L. Szymczak): 133-174. Krosno Odrzańskie.

Marciszak, A., 2011. Carnivores from Naciekowa Cave (Połom Hill, Kaczawskie Mts., south-west Poland). In: Guidebook of the 17th International Cave Bear Conference, September 15-18, 2011 (eds. D. Döppes, U. Jogerm, R. Nielbock and W. Rosendahl): 20. Einhornhöhle, Harz, Germany.

Marciszak, A., 2012. Mustelids (Mustelidae, Carnivora, Mammalia) from the Pleistocene of Poland. Unpublished Ph.D. thesis, University of Wrocław, Wrocław.

Marciszak, A., 2014. Fauna kopalna Jaskini Niedźwiedziej. Drapieżne (in Polish). In: Materiały 48. Sympozjum Speleologicznego (eds. K. Stefaniak, U. Ratajczak and W. Wróblewski): 10-12. Kletno, 16-19.10.2014r

Marciszak, A., Socha, P., Nadachowski, A., Stefaniak, K., 2011 Carnivores from Biśnik Cave. Quaternaire. Hors-serie, 4 101-106.

Marciszak, A., Stefaniak, K., Gornig, W., 2016. Fossil theriofauna from the Sudety Mts (SW Poland). The state of research. Cranium, 33: 31-41.

Marciszak, A., Gornig, W., Stefaniak, K., 2017. Large mammals (carnivores, artiodactyls) from Solna Jama Cave (Bystrzyckie Mts, Southwestern Poland) in the context of faunal changes in the postglacial period of Central Europe. Palaeontologia Electronica, 20: 1-37.

Marciszak, A., Kotowski, A., Przybylski, B., Badura, J. Wiśniewski, A., Stefaniak, K., 2019a. Large mammals from historical collections of open-air sites of Silesia (southern Poland) with special reference to carnivores and rhinoceros. Historical Biology, 31: 696-730.

Marciszak, A., Schouwenburg, Ch., Lipecki, G., Talamo, S., Shpansky, A., Malikov, D., Gornig, W., 2019b. Steppe brown bear Ursus arctos "priscus" from the Late Pleistocene of Europe. Quaternary International, 534: 158-170.

Marciszak, A., Sobczyk, A., Kasprzak, M., Gornig, W., Ratajczak, U. Wiśniewski, A., Stefaniak, K., 2020. Taphonomic and paleoecological aspects of large mammals from Sudety Mts. (Silesia, SW Poland), with particular interest to the carnivores. Quaternary International, https://doi.org/10.1016/j.quaint.2019.11.009

Maslin, M.A., Ridgewell, A., 2005. Mid-Pleistocene Revolution and the eccentricity myth. Geological Society, 247: 19-34.

Matheson, C., 1942. Man and bear in Europe. Antiquity, 142 151-159.

Mattson, D.J., Merrill, T., 2002. Extirpations of grizzly bears in the contiguous United States, 1850-2000. Conservation Biology, 16: $1123-1136$

Mazák, V., 1979. Die Tiger. A. Ziemsen Verlag, Wittenberg Lutherstadt.

Mazák, V., 1981. Panthera tigris. Mammalian Species, 152: 1-8.

Mäuser, M., 1987. Geologische und paläontologische Untersuchungen an der altpleistozänen Säugetier-Fundstelle Würzburg-Schalksberg. Müncher Geowissenschaftliche Abhandlungen, Reihe A, Geologie und Paläontologie, 11: 1-78.

Mazza, P., Rustioni, M., 1992. Morphometric revision of the Eurasian species Ursus etruscus Cuvier. Palaeontographia Italica, 79: 101-146.

Mazza, P., Rustioni, M., 1994. On the phylogeny of Eurasian bears. Palaeontographica A, 230: 1-38.

Mazza, P.P.A., Rustioni, M., Garcia, N., 2005. First discovery of a well-preserved skull of Ursus gr. thibetanus in the latest Pliocene of central Italy. In: Abstract book of the International Congress Cadre biostratigraphique de la fin du Pliocène et du Pléistocène inférieur ( $3 \mathrm{Ma}$ à 780000 ans) en Europe méridionale, 20-22 May 2005, Tende, France.

Mirosław-Grabowska, J., Cyrek, K., 2009. Archaeology and stratigraphy of the Jasna Strzegowska Cave. Studies of the Faculty of Earth Sciences, University of Silesia, 56: 273-282.

Molenda, O., 1984. Szczątki kostne zwierząt z wczesnośredniowiecznej Rzymówki, gmina Złotoryja, województwo legnickie (in Polish). Roczniki Akademii Rolniczej w Poznaniu, 154: 55-65.

Montoya, P., Ginsburg, L., Alberdi, M.T., Van der Made, J., Morales, J., Soria, M.D., 2006. Fossil large mammals from the early Pliocene locality of Alcoy (Spain) and their importance in biostratigraphy. Geodiversitas, 28: 137-173.

Morales, J., Aguirre, E., 1976. Carnívoros de Venta del Moro. Trabajos sobre Neógeno-Cuaternario, 5: 31-81.

Morlo, M., Kundrát, M., 2001. The first carnivoran fauna from the Ruscinium (Early Pliocene, MN 15) of Germany. Paläontologische Zeitschrift, 75: 163-187.

Moullé, P.-E., 1992. Les grands mammifères du Pleistocène inferieur de la grotte du Vallonnet (Roquebrune-Cap-Martin, Alpes-Maritimes). Etude paléontologique des Carnivores, Equidé, Suidé et Bovidés. Ph.D. Dissertation. Museum National d'Hisroire Naturelle à l'Institut de Paléontologie Humaine, Paris.

Mörs, T., Hocht, F.v.d., Wutzler, B., 2000. Die erste Wirbeltierfauna aus der miozänen Braunkohle der Niederrheinischen Bucht (Ville-Schichten, Tagebau Hambach). Paläontologische Zeitschrift, 74: 145-170.

Münzel, S.C., Stiller, M., Hofreiter, M., Mittnik, A., Conard, N.J., Bocherens, H., 2011. Pleistocene bears in the Swabian Jura (Germany): genetic replacement, ecological displacement, extinctions and survival. Quaternary International, 245: 1-13.

Muzolf, B., Stefaniak, K., Tomek, T., Wertz, K., Socha, P., Cyrek, K., Mirosław-Grabowska, J., Madeyska, T., Nadachowski, A., 2009. Multiculturate sites on Mt. Birów in Podzamcze. Studies of the Faculty of Earth Sciences, University of Silesia, 56: 283-294.

Musil, R., 1964. Die Braunbären aus dem Ende des lezten Glazials. Časopis Moravského Musea, Vědy přirodni, 49: 83-102.

Musil, R., 2001. Die Ursiden-Reste aus der Unterpleistozän von Untermassfeld. Monographien des Römisch-Germanischen Zentralsmuseums, 40: 633-658.

Musil, R., 2018. Phenological analysis of the Last Glacial vertebrates from the territory of Moravia (the Czech Republic). Conti- 
nuity and change in faunistic communities. Fossil Imprint, $\mathbf{7 4}$ 199-236.

Müller, A., 1872. Ueber drei in der Provinz Ostpreussen ausgegrabene Bärenschädel. Schriften der Königlichen Physikalisch-Ökonomischen Gesellschaft zu Königsberg, 12 $1-22$.

Münzel, S.C., Stiller, M., Hofreiter, M., Mittnik, A., Conard, N.J., Bocherens, H., 2011. Pleistocene bears in the Swabian Jura (Germany): genetic replacement, ecological displacement, extinctions and survival. Quaternary International, 245: 225-237.

Myczkowski, K., 1959. Les résultats de l'examen des restes ostéologiques et des mollusques du haut moyen âge livrés par la station Ostrów Tumski a Wrocław au cours des campagnes 1950-1957 (in Polish with French summary). Przegląd Archeologiczny, 12: 150-171.

Nadachowski, A., Pawłowski, J., Stworzewicz, E., 1989. Charakterystyka stanowisk i ich korelacja stratygraficzna. Folia Quaternaria, 59-60: 5-19.

Nadachowski, A., Żarski, M., Urbanowski, M., Wojtal, P., Miękina, B., Lipecki, G., Ochman, K., Krawczyk, M., Jakubowski, G., Tomek, T., 2009. Late Pleistocene environment of the Częstochowa Upland (Poland) reconstructed on the basis of faunistic evidence from archaeological cave sites. Institute of Systematics and Evolution of Animals Polish Academy of Sciences, Kraków.

Nadachowski, A., Lipecki, G., Stefaniak, K., Lorenc, M., Wojtal, P., 2008. Extinction of the cave bear (Ursus spelaeus) in Central Europe (in Polish with English summary). In: Archaeozoological research in Poland and Middle-East Europe, data - methods interpretations (eds. D. Makowiecki, R. Abramowicz, D. Abramowicz, K. Smiarowski and M. Makohonienko): 76-78. Bogucki Wydawnictwo Naukowe, Poznań.

Nowakowski, D., Stefaniak, K., 2015. Pathological changes of the cranium of a young female cave bear (Ursus spelaeus R.) - a case study (the Sudety Mts., Poland). International Journal of Osteoarchaeology, 25: 119-125.

Ognev, S.I., 1935. Mammals of U.S.S.R. and adjacement countries. Part 3. Carnivores (Fissipedia and Pinnipedia). Nauka, Moscow.

Oldfield, C.C., McHenry, C.R., Clausen, P.D., Chamoli, U., Parr, W.C.H., Stynder, D.D., Wroe, S., 2011. Finite element analysis of ursid cranial mechanics and the prediction of feeding behaviour in the extinct giant Agriotherium africanum. Journal of Zoology, 286: 163-170.

Olive, F., 2006. Évolution des grands Carnivores au Plio-Pléistocène en Afrique et en Europe occidentale. L'anthropologie, 110: 850-869.

Ossowski, G., 1880. Sprawozdanie z badań geologicznoantropologicznych dokonanych w 1879 w jaskiniach okolic Krakowa (in Polish). Zbiór Wiadomości do Antropologii Krajowej, 4: 35-57.

Ossowski, G., 1881. Drugie sprawozdanie $z$ badań geologiczno-antropologicznych w jaskiniach okolic Krakowa w r. 1880 (in Polish). Zbiór Wiadomości do Antropologii Krajowej, 5: $18-46$.

Ossowski, G., 1883a. O szczątkach fauny dyluwialnej znalezionych w namule jaskiń wąwozu mnikowskiego (in Polish). Sprawozdanie Komisji Fizjograficznej, 17: 91-103.

Ossowski, G., 1883b. Czwarte sprawozdanie $z$ badań antropologiczno-archeologicznych w jaskiniach okolic Krakowa w 1882 (in Polish). Zbiór Wiadomości do Antropologii Krajowej, 7: $66-88$.

Ossowski, G., 1884. Sprawozdanie z badań paleo-etnologicznych w jaskiniach okolic Ojcowa w r. 1883 (in Polish). Zbiór Wiadomości do Antropologii Krajowej, 8: 61-87.

Ossowski, G., 1885. Jaskinie okolic Ojcowa pod względem paleo-etnologicznym (in Polish). Pamiętnik Akademii Umiejętności, Wydział Matematyczno-Przyrodniczy, 11: 1-60.

Ossowski, G., 1887a. Sprawozdanie z badań paleo-etnologicznych w jaskiniach okolic Ojcowa w r. 1886 (in Polish). Zbiór Wiadomości do Antropologii Krajowej, 11: 12-32.

Ossowski, G., 1887b. Fouillos de la Caverne de Wierzchowska-Gorna en Pologne. Antiqua, 2: 37-47.
Ossowski, G., 1890. O jaskini Bębłowskiej (in Polish). Rozprawy i Sprawozdania Wydziału Matematyczno-Przyrodniczego Akademii Umiejętności, 20: 8-16.

Pacher, M., 1997. Der Höhlenbärenkult aus ethnologischer Sicht Wissenschaftliche Mitteilungen Niederösterreichisches Landesmuseum, 10: 251-375.

Pacher, M., 2007. The type specimen of Ursus priscus Goldfuss, 1810 and the uncertain status of Late Pleistocene brown bears. Neues Jahrbuch für Geologie und Paläontologie, Abhandlungen, 245: 331-339.

Pacher, M., Stuart, A.J., 2009. Extinction chronology and palaeobiology of the cave bear (Ursus spelaeus). Boreas, 38: 189-206.

Parfitt, S.A., 1999. Mammalia. In: A Middle Pleistocene hominid site at Eartham Quarry, Boxgrove, West Sussex (eds. M.B. Roberts and S.A. Parfitt): 197-290. University College London, London.

Pax, F., 1921. Die Tierwelt Schlesiens. G. Fischer, Jena.

Pax, F., 1925. Wirbeltierfauna von Schlesien. Gebr. Borntraeger, Berlin.

Pax, F., 1937. Die Säugetierfauna des Glatzer Schneeberges. 2. Die rezenten Säugetiere. Beiträge zur Biologie des Glatzer Schneeberges, 3: 217-136.

Pax, F., 1955. Die zoologische Kenntnis Schlesiens bis zum Ausgange des 18. Jahrhunderts. Jahrbuch der Schlesischer Friedrich-Wilhelms-Universität zu Breslau, 1: 143-181.

Pax, F., Maschke, K., 1935. Höhlenfauna des Glatzer Schneeberges. Die rezente Metazoenfauna. Beiträge zur Biologie des Glatzer Schneeberges, 1: 4-72.

Pérez-Ramos, A., Kupczik, K., Van Heteren, A.H., Rabeder, G., Grandal-D'Anglade, A., Pastor, F.J., Serrano, F.J., Figueirido, B., 2018. A three-dimensional analysis of tooth-root morphology in living bears and implications for feeding behaviour in the extinct cave bear. Historical Biology, 31: 461-473.

Pérez-Ramos, A., Tseng, Z.J., Grandal-D’Anglade, A., Rabeder, G., Pastor, F.J., Figueirido, B. 2020. Biomechanical simulations reveal a trade-off between adaptation to glacial climate and dietary niche versatility in European cave bears. Science advances, 6: eaay 9462 .

Petrucci, M., Sardella, R., 2009. Ursus etruscus Cuvier, 1823 from the Early Pleistocene of Monte Argentario (Southern Tuscany, Central Italy). Bollettino della Societŕ Paleontologica Italiana, 48: 89-94.

Piątkowska-Małecka, J., Anc, K., Chormańska, A., Gągała, M., Kaczyńska, J., Kur, A., 2010. Gospodarowanie zwierzętami na osadzie otwartej kultury łużyckiej w Grzybianach koło Legnicy, stanowisko 1, woj. dolnośląskie (in Polish). Światowit B, 49: 49-67.

Pidoplichko, I.G., 1956. Materialy do Vyvchennia Mynulykh Faun URSR. Vydavnytsvo AN URSR, Kyiv.

Piotrowska, N., Goslar, T., 2002. Preparation of bone samples in the Gliwice radiocarbon laboratory for AMS radiocarbon dating. Isotopic Environmental Health Studies, 38: 1-9.

Popović, D., Baca, M., Stefaniak, K., Lipecki, G., Nadachowski, A., Marciszak, A., Sabol, M., Ridush, B., Roblíćková, M., Káńa, V., Obada, T., Stankovic, A., Mackiewicz, P., 2015. Genetic studies of cave bear (Ursus ingressus) populations from Central and Eastern Europe. In: 21st International Cave Bear Symposium, Leiden, Neatherlands. Program and Abstracts: 28, WPZ, Leiden.

Porth, E., 1857. Die Höhle von Ober-Langenau mit Dachsresten. Jahrbuch der Kaisserlischen Königlichen Geologischen Reichsanstalt, 8: 169.

Prat, F., Thibault, C., 1976. Le Gisement de Nauterie ŕ la Romieu (Gers). Fouilles de 1967 a 1973. Nauterie I. Mémoires du Muséum National d'Histoire Naturelle, Nouvelle série, Série C, Sciences de la Terre, 35: 1-82.

Prószyński, M., 1952. Notes sûr la géologie du bassin de la rivière de Bug (in Polish with French summary). Biuletyn Państwowego Instytutu Geologicznego, 65: 313-340.

Pulina, M., 1977. Zjawiska krasowe w Sudetach polskich (in Polish). Dokumentacja Geograficzna, 2-3: 118.

Pulina, M., 1996. Jaskinie Sudetów (in Polish). Polskie Towarzystwo Przyjaciół Nauk o Ziemi, Warszawa. 
Qiu, Z.-X., Deng, T., Wang, B.-Y., 2014. A Late Miocene Ursavus skull from Guanghe, Gansu, China. Vertebrata Palasiatica, 52 265-302.

Qiu, Z.D., Qiu, Z.X., 2013. Early Miocene Xiejiahe and Sihong fossi localities and their faunas, eastern China. In: Fossil Mammals of Asia (eds. X.M. Wang, L.J. Flynn and M. Fortelius): 142-154. Columbia University Press, New York.

Rabeder, G., Frischauf, Ch., 2016. Fossile Bären in Höhlen. In Höhlen und Karst in Österreich (eds. C. Spötl, L. Plan and E. Christian): 183-198. Oberösterreichisches Landesmuseum, Wien.

Rabeder, G., Hofreiter, M., 2004. Der neue Stammbaum der alpinen Höhlenbären. Die Höhle, 55: 1-19.

Rabeder, G., Hofreiter, M., Nagel, D., Withalm, G., 2004a. New taxa of Alpine cave bears (Ursidae, Carnivora). Cahiers Scientifiques-Muséum d'Histoire Naturelle de Lyon, 2: 49-67.

Rabeder, G., Hofreiter, M., Withalm, G., 2004b. The systematic position of the Cave Bear from Potoćka zijalka (Slovenia) Mitteilungen der Kommission für Quartärforschung der Österreichischen Akademie der Wissenschaften, 13: 197-200.

Rabeder, G., Nagel, D., Pacher, M., 2000. Der Höhlenbär. Jan Thorbecke Verlag, Stuttgart.

Rabeder, G., Pacher, M., Withalm, G., 2010. Early Pleistocene bear remains from Deutsch-Altenburg (Lower Austria). Mitteilungen der Kommission für Quartärforschung de Österreichischen Akademie der Wissenschaften, 17: 1-135.

Radziejowski, J., 1967. Niedźwiedź jaskiniowy z Wiercicy (in Polish). Niphargus, Oddział Polskiego Towarzystwa Turystyczno-Krajoznawczego, Częstochowa, 37

Reichenau, W.V., 1904. Über eine neue fossile Bären-Art Ursus deningeri aus den fluviatilen Sanden von Mosbach. Jahrbücher des Nassauischen Vereins für Naturkunde, 57: 1-11.

Reichenau, W.V., 1906. Beiträge zur näheren Kenntnis der Carnivoren aus den Sanden von Mauer und Mosbach Abhandlunge der Grossherzoglich Hessischen Geologischen Landesanstalt zu Darmstadt, 4: 189-313.

Reimer, P.J., Bard, E., Bayliss, A., Beck, J.W., Blackwell, P.G. Ramsey, Ch.B., Buck, C.E., Cheng, H., Edwards, R.L., Friedrich, M., Grootes, P.M., Guilderson, T.P., Haflidason, H., Hajdas, I., Hatté, Ch, Heaton, T.J., Hoffmann, D.L., Hogg, A.G., Hughen, K.A., Kaiser, K.F., Kromer, B., Manning, S.W., Niu, M., Reimer, R.W., Richards, D.A., Scott, E.M., Southon, J.R., Staff, R.A., Turney, ChS.M., Plicht, J.V.D., 2013. IntCal13 and Marine13 radiocarbon age calibration curves, $0-50,000$ years cal BP. Radiocarbon, 55: 1869-1887.

Reynolds, S.H., 1906. A monograph of the British Pleistocene Mammalia. Part. II. The bears. The Paleontographical Society, London.

Rode, K., 1931. Über die Bären von Taubach und Ehringsdorf Paläontologische Zeitschrift, 13: 61-72.

Rode, K., 1935. Untersuchungen uber das Gebiss der Bären Monographien zur Geologie und Paläontologie, 2: 1-162.

Rosin, A.D., 1956. Verhn'opliocenova fauna pivdnia Ukrainy (in Ukrainian). Praci Odes'koho Derzhavnoho Pedagogichnoho Instytutu K.D. Ushinskoho, 14: 33-84.

Römer, F., 1875. Über einem am Kitzelberg bei Kauffung gefunden Bärenunterkiefer. Jahresbericht der Schlesischen Gesellschaft für vaterländische Kultur, 52: 23.

Römer, F., 1877. Schadel des Höhlenbären aus der Höhle von Ojcov. Jahresbericht der Schlesischen Gesellschaft für vaterländische Kultur, 54: 37.

Römer, F., 1879. Über die Vervendung des Inhalts der Knochenhöhlen zwischen Olkusz und Ojców in Polen als Düngungsmittel und über neue Funde von fossilen Wirbelthierreste in dieser Hohlen Jahresbericht der Schlesischen Gesellschaft für vaterländische Kultur, 56: 47-49.

Römer, F., 1883. Die Knochenhöhlen von Ojców in Polen. Palaeontographica, 29: 1-41.

Ruprecht, A.L., 1965. Kopalne czaszki niedźwiedzia brunatnego Ursus arctos L. z okolic Ciechocinka (in Polish). Przegląd Zoologiczny, 9: 422-426.
Ruprecht, A.L., 1992. Stanowisko systematyczne czaszk niedźwiedziej z przykościelnego muzeum w Raciążku na Kujawach (in Polish). Przegląd Zoologiczny, 36: 207-210.

Rustioni, M., Mazza, P., 1993. The genus Ursus in Eurasia: dispersal events and stratigraphical significance. Rivista Italiana di Paleontologia e Stratigrafia, 98: 487-494.

Ryziewicz, Z., 1954. O ssakach mioceńskich znalezionych w okolicach Opola (in Polish). Sprawozdania Wrocławskiego Towarzystwa Naukowego, 9: 105.

Ryziewiecz, Z., 1969. Badania nad niedźwiedziami plioceńskimi (in Polish with English summary). Acta Palaeontologica Polonica, 14: 200-243.

Rzebik-Kowalska, B., 2009. Biodiversity of Polish fossil insectivores (Erinaceomorpha, Soricomorpha, Insectivora, Mammalia) compared to the European and global faunas. Institute of Systematics and Evolution of Animals, Polish Academy of Sciences, Kraków.

Sabol, M., 2001a. Fossil and subfossil findings of brown bears from selected localities in Slovakia. Slovak Geological Magazine, 7: 3-17.

Sabol, M., 2001b. Fossil brown bears of Slovakia. Cadernos Laboratorium Xeolóxico de Laxe, 26: 311-316.

Samsonowicz, J., 1934. Zjawiska krasowe i trzeciorzedowa brekcja kostna w Wężach pod Działoszynem (in Polish). Zabytki Przyrody Nieożywionej Ziem Rzeczypospolitej Polskiej, 3: 151-162.

Schlosser, M., 1899a. Parailurus anglicus és Ursus böckhi a Baróth-Köpeczi lignitből, Háromszék vármegyében (in Hungarian). Magyar Királyi Földtani Intézet Évkönyve, 13: 59-91.

Schlosser, M., 1899b. Ueber die Bären und bärenähnlichen Formen des europäischen Tertiärs. Palaeontographica, 46: 95-148.

Schlosser, M., 1899c. Parailurus anglicus und Ursus böckhi aus den Ligniten von Baróth-Köpecz, Comitat Háromszék in Ungarn. Mittheilungen aus dem Jahrbuch der königlichen Ungarischen Geologischen Anstalt, 13: 65-95.

Schramm, Z., Kranz, I., 1978. Materiał kostny zwierząt dzikich mięsożernych z wykopalisk w Santoku (in Polish). Rocznik Akademii Rolniczej w Poznaniu, 103: 31-42.

Sellards, E.H., 1916. Fossil vertebrates from Florida: a new Miocene fauna; new Pliocene species; the Pleistocene fauna. Florida State Geological Survey Annual Report, 8: 77-119.

Skutil, J., 1961. Revize zpráv o paleontologických a paleolitických (?) nálezech ze Svobody nad Úpou v Podkrkonoší (in Czech). Antropozoikum, 11: 147-151.

Sobociński, M., 1961. Zwierzęta udomowione i łowne z młodszej epoki kamienia w Nosocicach w pow. głogowskim (in Polish). Przegląd Archeologiczny, 13: 122-137.

Sobociński, M., 1973. Materiał kostny zwierzecy z wykopalisk w Kaszowie, pow. Milicz (in Polish). Silesia Antiqua, 15: 249-263.

Sobociński, M., 1983. Materiał kostny zwierzęcy z wykopalisk w Santoku (in Polish). Roczniki Akademii Rolniczej w Poznaniu, 145: $118-144$

Soergel, W., 1926. Der Bär von Süßenborn. Ein Beitrag zur näheren Kenntnis der diluvialen Bären. Neues Jahrbuch für Mineralogie, Geologie und Paläontologie B, 1926: 115-156.

Soria, D., Morales, J., 1976. Hallazgo de un Ursido en el yacimiento de Layna (Soria). Trabajos sobre Neogeno Cuaternario, 5: 129-140.

Sorkin, B., 2006. Ecomorphology of the giant short-faced bears Agriotherium and Arctodus. Historical Biology, 18: 1-20.

Stach, J., 1953. Ursus wenzensis, nowy gatunek małego niedźwiedzia plioceńskiego (in Polish). Acta Geologica Polonica, 3: 103-136.

Stach, J., 1957. Agriotherium intermedium n. sp. from the Pliocene bone breccia of Węże. Acta Palaeontologica Polonica, 2: 1-17.

Stefaniak, K., 2015. Neogene and Quaternary Cervidae from Poland. Institute of Systematics and Evolution of Animals, Polish Academy of Sciences, Kraków.

Stefaniak, K., Marciszak, A., 2009. Large mammals (Carnivora, Ungulata) from Pleistocene sediments of the Biśnik Cave. Stud- 
ies of the Faculty of Earth Sciences, University of Silesia, $\mathbf{5 6}$ 225-254.

Stefaniak, K., Bieroński, J., 2009. Caves and rock shelters of the Eastern Sudetes - catalogue of important speleological features. Studies of the Faculty of Earth Sciences, University of Silesia, 56: 515-534.

Stefaniak, K., Nadachowski, A., Tomek, T., Socha, P., 2009. Palaeontological studies in the Czestochowa Upland. Studies of the Faculty of Earth Sciences, University of Silesia, 56: 85-144.

Stehlin, H.G., 1907. Les Types du Lophiodon de Montpellier de Cuvier (Hyaenarctos insignis P. Gerv.). Bulletin de la Société géologique de France, 7: 219-223.

Stiller, M., Baryshnikov, G.F., Bocherens, H., Grandal d'Anglade, A., Hilpert, B., Münzel, S.C., Pinhasi, R., Rabeder, G., Rosendahl, W., Trinkaus, E., Hofreiter, M., Knapp, M., 2010. Withering away $-25,000$ years of genetic decline preceded cave bear extinction. Molecular Biology and Evolution, 27: 975-978.

Stiller, M., Molak, M., Prost, S., Rabeder, G., Baryshnikov, G.F., Rosendahl, W., Münzel, S., Bocherens, H., Grandald'Anglade, A., Hilpert, B., Germonpré, M., Stasyk, O., Pinhasi, R., Tintori, A., Rohland, N., Mohandesan, E., Ho, S.Y.W., Hofreiter, M., Knapp, M., 2014. Mitochondrial DNA diver sity and evolution of the Pleistocene cave bear complex. Quaternary International, 339-340: 224-231.

Stuart, A.J., Lister, A.M., 2011. Extinction chronology of the cave lion Panthera spelaea. Quaternary Science Reviews, 30: 2329-2340.

Storch, G., Franzen, J.L., Malec, F., 1973. Die altpleistozäne Säugerfauna (Mammalia) von Hohensülzen bei Worms. Senckenbergiana Lethaea, 54: 311-343.

Thenius, E., 1947. Ursavus ehrenbergi aus dem Pont von Euböa (Griechenland). Sitzungsberichte der Akademie der Wissenschaften in Wien, Mathematisch-Naturwissenschaftlichen Klasse, 156: 225-249.

Thenius, E., 1949a. Die Tortone Säugetierfauna von Neudorf an der March (ČSR) und ihre Bedeutung für die Helvet-Torton- Grenze. Anzeiger der Österreichische Akademie der Wissenschaften, Mathematisch-Naturwissenschatliche Klasse, 7: 160-171.

Thenius, E., 1949b. Die Carnivoren von Göriach (Steiermark). Sitzungsberichte der Akademie der Wissenschaften in Wien, Mathematisch-Naturwissenschaftlichen Klasse, 158: 695-762.

Thenius, E., 1949. Die Carnivoren von Göriach (Steiermark). Sitzungsberichte der Akademie der Wissenschaften in Wien, Mathematisch-Naturwissenschaftlichen Klasse, Abt. 1, 158: 695-762.

Thenius, E., 1956. Zur Kenntnis der fossilen Braunbären (Ursidae, Mammalia). Sitzungsberichte der Österreichische Akademie der Wissenschaften. Mathematisch Naturwissenschaftliche Klasse, Abteilung 1: Biologie, Mineralogie, Erdkunde und Verwandte Wissenschaften, 165: 153-172.

Tsoukala, E., 1991. Contribution to the study of the Pleistocene fauna of large mammals (Carnivora, Perissodactyla, Artiodactyla) from Petralona Cave (Chalkidiki, N. Greece). Preliminary report. Comptes Rendus de l'Académie des Sciences. Série II, Mecanique, Physique, Chimie, Sciences de la Terre, Sciences de l'Univers, 312: 331-336.

Turner, A., 2009. The evolution of the guild of large Carnivora of the British Isles during the Middle and Late Pleistocene. Journal of Quaternary Science, 24: 991-1005.

Vaisfeld, M.A., Chestin, I.E., 1994. Bears: brown bear, polar bear, Asian black bear. Nauka, Moscow.

Van Heteren, A.H., Maclarnon, A., Rae, T.C., Soligo, C., 2009. Cave bears and their closest living relatives: a $3 \mathrm{D}$ geometric morphometrical approach to the functional morphology of the cave bear Ursus spelaeus. Acta Carstologica Slovaca, 47: 33-46.

Van Heteren, A.H., Maclarnon, A., Rae, T.C., 2014. Functional morphology of the cave bear (Ursus spelaeus) cranium: a three-dimensional geometric morphometric analysis. Quaternary International, 339-340: 209-216.
Vekua, A.K., 1972. Kvabebskaya fauna akchagylskikh pozvonochnykh. Nauka, Moskva.

Vereshchagin, A.N., 1959. Mlekopitayushchiye Kavkaza; istoriya formirovaniya fauny. Izdatelstvo AN SSSR, Moskva-Leningrad.

Wagner, A., 1837. Gelehrte Anzeigen herausgegeben von Mitgliedern der Kreis Bayer (in German). Paläontologische Abhandlungen, Gelehrte Anzeigen, 5: 334-336.

Wagner, J., 2004. A taxonomic revision of bears from selected Biharian localities of the Czech Republic. A preliminary report: I. C 718, Chlum I, Chlum IV. Cahiers Scientifiques, Hors Série, 2: 139-144.

Wagner, J., 2005. A taxonomic revision of bears from selected Biharian localities of the Czech Republic. A preliminary report. II. Koneprusy caves - an old collection. Bulletin de la Société d'Histoire Naturelle de Toulouse et de Midi-Pyrenees, 141: 51-54.

Wagner, J., 2006. A list of craniodental material of Pliocene Ursids (genus Ursus) in the collection of Naturhistorisches Museum Basel. Scientific Annals, School of Geology Aristotle University of Thessaloniki, special volume, 98: 127-139.

Wagner, J., 2010. Pliocene to early Middle Pleistocene ursine bears in Europe: a taxonomic overview. Journal of the National Museum of Prague, Natural History Series, 179: 197-215.

Wagner, J., Čermák, S., 2012. Revision of the early Middle Pleistocene bears (Ursidae, Mammalia) of Central Europe, with special respect to possible co-occurrence of spelaeoid and arctoid lineages. Bulletin of Geosciences, 87: 461-496.

Wagner, J., Čermák, S., Horáček, I., 2011. The presence of Ursus ex. gr. minimus-thibetanus in the late Villányian and its position among the Pliocene and Pleistocene black bears in Europe. Quaternaire, Hors-série, 4: 39-58.

Wagner, J., Gasparik, M., 2014. Research history of Pleistocene faunas in Gombasek quarry (Slovakia), with comments to the type specimen and the type locality of Ursus deningeri gombaszogensis Kretzoi, 1938. Fragmenta Palaeontologica Hungarica, 31: 125-143.

Wagner, J., Lipecki, G., Krawczyk, M., 2008. New evidence of Ursus minimus from the territory of Poland. Stalactite, 58: 78-80.

Wagner, J., Sabol, M., 2007. Remarks on Biharian bears (Ursidae: Ursus) from the territory of Slovakia. Scripta Facultatis Scientiarum Naturalium Universitatis Masarykianae Brunensis, 35: 159-164.

Wegner, R.N., 1908. Zur Kenntnis der Säugetierfauna des Obermiocäns bei Opplen (Oberlschlesien). Verhandlungen der Kaiserlich-Königlichen Geologischen Reichsanstalt, 1908: 11-117.

Wegner, R.N., 1913. Tertiär und umgelagerte Kreide bei Oppeln (Oberschlesien). Palaeontographica, 60: 175-274.

Wenke, R., 1933. Die diluvialen Säugetierreste vom Kitzelberge bei Kauffung. Wanderer in Riesengebirge, 53: 146-147.

Wiśniewski, A., Stefaniak, K., Wojtal, P., Zych, J., Nadachowski, A., Musil, R., Badura, J., Przybylski, B., 2009. Archaeofauna or palaeontological record? Remarks on Pleistocene fauna from Silesia. Sprawozdania Archeologiczne, 61: 1-62.

Wiszniowska, T., 1967. Nowe znalezisko paleontologiczne w Sudetach (in Polish). Przegląd Zoologiczny, 11: 430-433.

Wiszniowska, T., 1970. Wstępne wyniki badań fauny kopalnej w Jaskini Niedźwiedziej (in Polish). Acta Universitatis Wratislaviensis, 127: 45-70.

Wiszniowska, T., 1976. Niedźwiedź jaskiniowy z Kletna i innych jaskiń Polski (in Polish). Acta Universitatis Wratislaviensis, 311: $1-75$.

Wiszniowska, T., 1978. Panthera spelaea (Goldfuss) z Jaskini Niedźwiedziej w Kletnie (in Polish). Acta Universitatis Wratislaviensis, 329: 113-141.

Wiszniowska, T., 1986. Szczątki fauny w namuliskach jaskiń na Śląsku (in Polish). Prace Komisji Archeologicznej Polskiej Akademii Nauk Ossolineum, 3: 9-19.

Wiszniowska, T., 1989a. Middle Pleistocene Carnivora (Mammalia) from Kozi Grzbiet in the Świętokrzyskie Mts., Poland. Acta Zoologica Cracoviensia, 32: 589-630. 
Wiszniowska, T., 1989b. Kopalne szczątki zwierzęce (in Polish). In Jaskinia Niedźwiedzia w Kletnie. Badania i udostępnianie (eds. A. Jahn, S. Kozłowski and T. Wiszniowska): 255-279. Zakład Narodowy imienia Ossolińskich, Wrocław-Warszawa.

Wiszniowska, T., Mackiewicz, P., Stefaniak, K., Socha, P., Nowakowski, D., Nadachowski, A., 2010. Dental enamel structure in fossil bears Ursus spelaeus and $U$. wenzensis (=minimus) in comparison to selected representatives of other Carnivora. In: Morphology and Systematics of Fossil Vertebrates (ed. D. Nowakowski): 125-142. DN Publisher, Wrocław.

Wojtal, P., 2007. Zooarchaeological studies of the Late Pleistocene sites in Poland. Institute of Systematics and Evolution of Animals, Polish Academy of Sciences, Krakòw.

Wojtal, P., Wilczyński, J., Nadachowski, A., Münzel, S.C., 2015. Gravettian hunting and exploitation of bears in Central Europe. Quaternary International, 359-360: 58-71.

Wolsan, M., 1989. Drapieżne - Carnivora (in Polish). Folia Quaternaria, 59-60: 177-197.

Wüst, W., 1956. Die paläolithisch-ethnographischen Bären-Riten und das Alt-Indogermanische. Quartär, 7-8: 154-165.

Wyrost, P., 1959. Z badań nad szczątkami kostnymi zwierzą mięsożernych (domowych i dziko żyjących) wczesnośredniowiecznego Wrocławia (in Polish). Przegląd Zoologiczny, 3: 84-90.

Wyrost, P., 1962. Wyniki ekspertyzy archeozoologicznej materiału kostnego z średniowiecznego stanowiska w Międzyrzeczu Wlkp. (in Polish). Archiwum Katedry Anatomii Zwierząt Akademii Rolniczej we Wrocławiu, Wrocław.

Wyrost, P., 1994. Dawna fauna Polski w świetle badań kostnych materiałów archeologicznych (in Polish). Roczniki Akademii Rolniczej w Poznaniu, 259: 155-176.

Wyrost, P., Chrzanowska, W., 1981. Szczątki kostne ssaków dziko żyjących z wczesnośredniowiecznego Wrocławia (in Polish). Roczniki Akademii Rolniczej w Poznaniu, 131: 163-175.

Wyrost, P., Chrzanowska, W., 1985. Ssaki średniowiecznej fauny Śląska w świetle badań archeozoologicznych (in Polish). In Dawna fauna Śląska w świetle badań archeozoologicznych (ed. P. Wyrost): 59-101. Polska Akademia Nauk, Wrocław.
Zapfe, H., 1948. Die altplistozänen Bären von Hundsheim in Niederösterreich. Jahrbuch der Geologischen Bundesanstalt, 91: 95-164

Zawisza, J., 1873. Niedźwiedź jaskiniowy z Jaskini Łokietkowej w Ojcowie (in Polish). Wiadomości Archeologiczne, 1: 1-7.

Zotz, L.F., 1931. Die altsteinzeitlichen Reste aus den Kauffunger Höhlen. Sudeta, 7: 1-5.

Zotz, L.F., 1934. Mensch der vorgeschichtlichen Zeit, aus denen der Schlesier wurde. Vorgeschichte und Rassenkunde, 122: 3-22.

Zotz, L.F., 1935a. Vom Höhlenbären. Altschlesische Blätter, 10: 86.

Zotz, L.F., 1935b. Ein neuer Fundplatz der Höhlenbärenjägerkultur. Nachrichtenblatt für Deutsche Vorzeit, 11: 189-190.

Zotz, L.F., 1935c. Wohplätze eiszeitlicher Höhlenbärenjäger in Schlesien. Forschungen und Fortschriften, 11: 406.

Zotz, L.F., 1936a. Die altsteinzeitlichen Fundplätze von Kauffung an der Katzbach. Altschlesiche Blätter, 11: 75-79.

Zotz, L.F., 1936b. Die der Höhlenbärenjägerkultur an der Katzbach. Schlesische Monatshefte, 13: 16-17.

Zotz, L.F., 1937a. Die schlesischen Höhlen und ihre eiszeitlichen Bewöhner. Wilhelm Gottlieb Korn Verlag, Breslau.

Zotz, L.F., 1937b. Altsteinzeitlicher Bärenkult in den Sudeten. Altschlesische Blätter, 12: 4-7.

Zotz, L.F., 1937c. Die Hellmichhöhle. Altschlesiche Blätter, 12: 119-121.

Zotz, L.F., 1939a. Die Altsteinzeit in Niederschlesien. Kabitsch Verlag, Leipzig.

Zotz, L.F., 1939b. Zur Altsteinzeit in Niederschlesien. Altschlesische Blätter, 14: 94-98.

Zotz, L.F., 1951. Altsteinzeitkunde Mitteleuropas. F. Enke Verlag, Stuttgart.

Żarski, M., Winter, H., Nadachowski, A., Urbanowski, M., Socha, P., Kenig, K., Marcinkowski, B., Krzemińska, E., Stefaniak, K., Nowaczewska, W., Marciszak, A., 2017. Stratigraphy and palaeoenvironment of Stajnia Cave (southern Poland) with regard to habitation of the site by Neanderthals. Geological Quarterly, 61 (2): 350-369. 